\title{
Racial Identity and Racial Socialization Attitudes of African- American Parents
}

Anita Jones Thomas

Loyola University Chicago

Follow this and additional works at: https://ecommons.luc.edu/luc_diss

Part of the Education Commons

\section{Recommended Citation}

Thomas, Anita Jones, "Racial Identity and Racial Socialization Attitudes of African-American Parents" (1994). Dissertations. 3499.

https://ecommons.luc.edu/luc_diss/3499

This Dissertation is brought to you for free and open access by the Theses and Dissertations at Loyola eCommons. It has been accepted for inclusion in Dissertations by an authorized administrator of Loyola eCommons. For more information, please contact ecommons@luc.edu. (c) $($ ) $\Theta \Theta$

This work is licensed under a Creative Commons Attribution-Noncommercial-No Derivative Works 3.0 License. Copyright (c) 1994 Anita Jones Thomas 
LOYOLA UNIVERSITY CHICAGO

RACIAL IDENTITY AND RACIAL SOCIALIZATION ATTITUDES OF AFRICAN-AMERICAN PARENTS

\author{
A DISSERTATION SUBMITTED TO \\ THE FACULTY OF THE GRADUATE SCHOOL \\ IN CANDIDACY FOR THE DEGREE OF \\ DOCTOR OF PHILOSOPHY
}

DEPARTMENT OF COUNSELING PSYCHOLOGY

BY

ANITA JONES THOMAS, M.A.

CHICAGO, ILLINOIS

JANUARY , 1995 
Copyright by Anita Jones Thomas, 1994

All Rights Reserved

ii 
ACKNOWLEDGEMENTS

I would like to thank Dr. Suzette L. Speight for serving as chair of this dissertation and for all of the support that she has given me throughout my graduate school career. Thanks are also given to Dr. Gloria Lewis and to Dr. Scott Solberg for serving on the dissertation committee.

Thanks are extended to Rev. Thurmond Coleman, Rev. Richard Gaines, Rev. John Crittenden and the members of First Baptist Church of Jeffersontown for participating in the research study. I extend my gratitude to Rev. Louis Coleman and the members of his church for participating as well. I would like to acknowledge Mrs. Anna Downey and Ms. Frances Lawson for helping me collect surveys.

Words could not express the appreciation I have to my parents, Melvin and Bernice Jones for their love and support. As with most things, I could not have completed this project without them. I would also like to acknowledge my sister, Sheila Jones, who offered endless support. Finally, I cannot begin to thank my husband, John Thomas, for years of support through graduate school, for proofreading papers, and for helping with the statistical analysis of this project. 
TABLE OF CONTENTS

ACKNOWLEDGEMENTS

LIST OF TABLES

Chapter

1. INTRODUCTION $\ldots \ldots \ldots \ldots \ldots \ldots \ldots \ldots \ldots \ldots \ldots \ldots \ldots$

Outline of the dissertation $\ldots \ldots \ldots \ldots \ldots \ldots, 7$

2. REVIEW OF THE LITERATURE ............... 8

Racial identity models............... 8

Racial identity of children and adolescents... 14

Parental influences on racial identity ..... 23

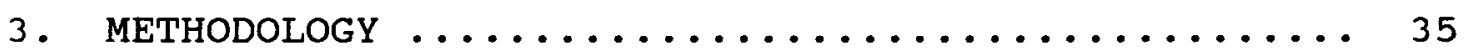

Participants .................... 35

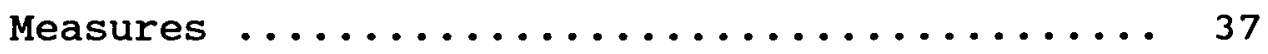

Procedures $\ldots \ldots \ldots \ldots \ldots \ldots \ldots \ldots \ldots \ldots \ldots .40$

Statistical analyses .............. 41

Research hypotheses $\ldots \ldots \ldots \ldots \ldots \ldots \ldots \ldots \ldots .42$

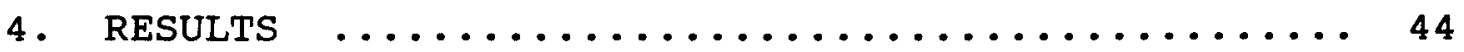

Quantitative results $\ldots \ldots \ldots \ldots \ldots \ldots \ldots \ldots \ldots 45$

Qualitative results ................... 51

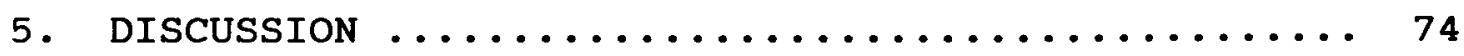

General research findings ............ 74

Limitations of the study $\ldots \ldots \ldots \ldots \ldots \ldots \ldots .62$

Future research suggestions ........... 86 
A. Parental Attitude scale ............... 90

B. Racial Identity Attitude scale

(Social Atttitude Scale).............. 95

C. Qualitative Racial Attitude Measure

(Parental survey) ...................... 98

D. Introductory letter .............. 102

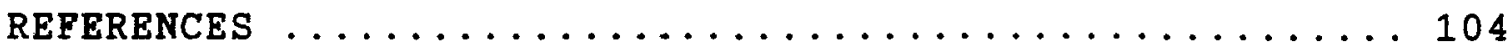

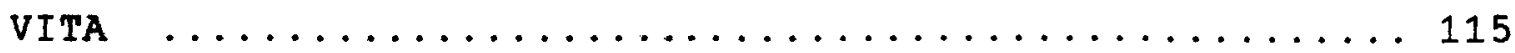




\section{LIST OF TABLES}

Table

Page

1. Demographic Frequencies According to Gender ..... 37

2. Mean Scores for Racial Identity and Socialization Attitudes .............................. 47

3. Correlation coefficients for RIAS Subscales and BPA Subscale ............................. 48

4. Categories of Importance of Racial Socialization .. 55

5. Racial Socialization Messages ............... 59

6. Racial Socialization Messages for Boys ......... 65

7. Racial Socialization Messages for Girls ........ 71 
CHAPTER I

\section{INTRODUCTION}

From birth, parents must nurture, protect and provide for their children. The role of parents is to socialize children, to enhance self-worth, and to help children develop a personal frame of reference for behaviors. Because of a history of racism and oppression in this country, African-Americans parents face the difficult task of developing positive global self-esteem, cultural identity, and personal identity in their children. Identity has been defined as an integration of self-concept and selfesteem with the perceptions of future development, and includes an awareness of group membership, expectations and privileges according to group membership, as well as restraints and social responsibilities (Spencer, 1988). This includes a sense of self-worth, individual personality characteristics, traits, and attributes, as well as an understanding and appreciation of the cultural/racial group.

Although research has focused on personal identity and reference group identity as separate entities, recent models have been postulated on racial identity which incorporate the two ideas. Personal identity includes self-concept and self-esteem, and group identity is defined as the amount of salience an individual holds for their particular racial or 
ethnic group (Cross, 1987). Racial and ethnic identity have been defined as attitudes and beliefs an individual holds about his/her particular racial/ethnic group and includes racial awareness, racial self-identification, racial attitudes, and racial behaviors (Rotheram \& Phinney, 1987). Models of racial identity development postulate that individuals move through stages of low salience towards their racial/ethnic group to an integration of cultural and mainstream beliefs. In the initial stage, individuals have low salience to racial issues. After a strong positive or negative racial encounter, the person experiences confusion about their racial identity and decides to seek their identity. The third stage includes emersion into the particular racial/ethnic group, including exclusive participation in racial/ethnic activities. The final stage includes an integration of values and beliefs from both the racial group and the majority culture (Cross, 1971, 1991; Smith, 1991: Atkinson, Morten, \& Sue, 1982).

Positive sense of self and racial identification has been empirically linked to increased psychological adaptation and functioning, increased self-esteem (Parham \& Helms, 1985a, 1985b; Carter, 1991), and success and achievement (Ward, 1990). Negative racial identity in African-Americans has been theoretically linked to low selfesteem, problems with psychological adjustment, low school achievement, school drop-outs, teenage pregnancy, gang 
involvement, eating disorders, drug abuse, and crime (Cross, 1991; Poussaint, 1990). Due to the potential consequences of negative racial identity, it is imperative that African-Americans develop a positive sense of self that includes a sense of racial pride.

The development of positive self-concept is enhanced by many factors, including cognitive, social, and affective development, as well as situational factors, such as the environment, peer relationships, and parental messages and racial socialization. Racial and cultural identity are influenced by the same cognitive and developmental factors, as well as the development of social perspective-taking (Whaley, 1993; Spencer, Swanson, \& Cunningham, 1991; Spencer, 1988; Alejandro-Wright, 1985; Phinney, 1991; Rotheram \& Phinney, 1987; Ramsey, 1987; McAdoo, 1985; Harrison, 1985; Gay, 1978). The family context is most important in the early development of the child's sense of self (Demo \& Hughes 1990; Spencer, Dobbs, \& Swanson, 1988). Socialization serves to transmit values, beliefs, and ideas around lifestyles, and is derived from cultural knowledge of adult tasks and competencies needed for adequate functioning within society (Harrison, Wilson, Pine, Chon, \& Buriel, $1990)$.

Racial socialization prepares children to cope with racism and oppression through developing a positive racial identity. Racial minority parents have the role of 
insulating children from the negative experiences of being in a minority status, and interpreting and translating experiences that occur outside the home in mixed racial and ethnic group settings (Jackson, McCullough, \& Gurin, 1988; Gibbs, 1990). Parents must help children develop positive racial identity and a sense of pride in their race (EddieQuarterly, 1994; Demo \& Hughes, 1990; Jackson et al., 1988) and promote biculturalism (Harrison et al., 1990). AfricanAmerican parents must help their children develop a positive racial identity and sense of self despite negative media images, stereotypes, oppression, and sometimes, impoverished conditions.

The history of racial identity development of AfricanAmerican children is extensive, dating to the early 1930's with the clark studies, however, relatively little is known about racial identity development in children and adolescents. Although many factors are involved with the development of positive self-esteem and self-concept in children and adolescents, parents are the most important resource, especially for young children. African-American parents are essential to the development of racial pride, and can often prevent children from experiencing confusion due to negative racial encounters or experiences. AfricanAmerican parents have the difficult task of socializing their children to develop positive self-esteem as well as a positive group identity (Greene, 1992a; Peters, 1985; 
Parham, 1993). Because negative racial identity has been theoretically associated with gang involvement, school dropouts, and negative self-esteem, it may be important for parents to help children develop positive racial identity. Although researchers acknowledge the role of parents in socialization and the development of identity (Spencer, 1988; Demo \& Hughes, 1990; Bowman \& Howard, 1985; Thornton, Chatters, Taylor, \& Allen, 1990), few have studied parental influences on racial identity development in children (Sanders Thompson, 1994; Stevenson, 1993; Helms, 1990; Katz, 1987; MCAdoo, 1985). According to spencer (1990), children may have positive or high self-esteem but hold Eurocentric attitudes which causes race dissonance unless an intervention is made, preferably by the parents. McAdoo (1985) states that negative identity in children can be attributed to an inadequate racial socialization process within the home.

Unfortunately, relatively few studies have examined the parental influence and childrearing beliefs on racial identity development. Some studies find that a large percentage of parents often do not socialize children for racial identity development, but that parents with more education are more likely to socialize children to have a positive sense of racial identity (Parham \& Williams, 1993; Thornton, et al., 1990; Bowman \& Howard, 1985). Branch and Newcombe (1980) found that even parents active in the Civil 
Rights movement often had little impact on children's racial identity. Similarly, spencer (1987) found that parents after the 1960's felt less need to teach Black values. The reasons why parents do not socialize their children to have a positive racial identity remain unclear. In addition, no study has examined parent's racial identity development and its effects on the childrearing and socialization beliefs (Boykin \& Toms, 1985).

As little research has been conducted, this study attempts to examine parental influences on the racial identity of African-American children and adolescents. Specifically, the study seeks to understand the relationship between racial identity attitudes and parental socialization and childrearing beliefs. The study also attempts to determine the specific racial messages taught to children as well as messages specific to gender.

Because of the exploratory nature of the study, the design included both qualitative and quantitative measures to identify racial identity attitudes and parental influences. The combination of measures provides triangulation of the data, and were included in this study to improve both the reliability and the validity of the study. This investigation examines three specific research questions. The first question explores the relationship between specific racial attitudes, as outlined in the racial identity development models, and socialization attitudes. 
The second purpose of the study is to determine specific racial messages that parents teach to children. Parental messages may also differ according to the gender of the children and the third research question seeks to determine messages geared towards each gender. The ultimate goal for the study is to develop a better understanding of racial socialization of children by determining the nature and relationship of racial identity attitudes to socialization attitudes, and to ascertain explicit messages.

\section{outline of the Dissertation}

The second chapter provides a critical review of the literature on racial identity in children, adolescents, and adults, as well as a summary of research on parental and racial socialization of African-American parents. The third chapter discusses the methodology utilized, and provides demographic characteristics of the participants, as well as statistical information on the instruments. The fourth chapter provides a summary of the results of the study. The fifth and final chapter provides a critical analysis of the data, implications of the study, a detailed discussion of limitations of the research, and suggestions for future research. 
CHAPTER II

REVIEW OF THE LITERATURE

This chapter will provide a summary of the research and theoretical literature on racial identity development. The chapter will begin by describing Black racial identity models that have been postulated. Research on the racial identity development of children and adolescents will be discussed, as well as a critique of the literature and research methodology. The review will also include an examination of theoretical literature on racial socialization, and a synopsis of the research exploring racial socialization. The chapter will conclude with a critique of the research on racial socialization. Racial Identity Models

Several models have been proposed to describe racial identity development that generally begin with individuals placing low salience on their race and end with acceptance and/or pride in their race (Smith, 1991; Cross, 1991; Parham, 1989). Smith (1991) developed a four-stage model that begins in childhood and continues through adulthood. Stage one includes a preoccupation with the self or the ethnicity of the person. This continues until an ethnic conflict occurs, which is the second stage. The person 
reorganizes and reaches a struggle to find a resolution in stage three until integration, stage four, is achieved. Similarly, Atkinson, Morten, and Sue (1982) developed a five stage model, that moves from conformity, dissonance, immersion into one's ethnic group, introspection and reorganization, and finally, integration and awareness. Myers, Speight, Highlen, Cox, Reynolds, Adams, and Hanley (1991) developed a comprehensive six-stage model of identity development based on Afrocentric psychology that moves a person from absence of conscious awareness, to dissonance, immersion, internalization, integration, transformation, and the acceptance of oneness with the entire community, both past, present, and future.

However, the most widely empirically studied model on racial identity is a five-stage model of psychological nigrescence developed by cross in 1971 and revised in 1991. The first stage, preencounter, is associated with a Eurocentric perspective. Individuals may not deny their Blackness but feel that race is irrelevant, that being Black is a social stigma due to social discrimination, or have anti-Black feelings or a negative reference group orientation. Stage two, encounter, occurs when a person experiences an event that causes them to challenge his/her preencounter beliefs, and is often accompanied by feelings of confusion, alarm, and depression, followed by guilt, anger, and anxiety. It is at this stage that the person 
makes the decision to develop a Black identity (Cross, 1991).

Immersion/emersion, the third stage, is often accompanied by intense feelings of anger as well as a developing sense of pride. Individuals immerse themselves in Blackness and only things related to Blackness or African culture have value. In emersion, individuals become less angry than immersion, and have less resentment towards Whites. At the end of this stage, individuals may become frustrated and regress to preencounter, become fixated at this stage, or "drop put" of the developmental cycle as they are satisfied with their identity.

other individuals enter the fourth and fifth stages, internalization and internalization/commitment in which they have a developed sense of Black pride. The person has high salience for the importance of race, and the anger felt during the immersion/emersion stage is now controlled and directed at racist institutions and other means of oppression. In internalization/commitment, people actively work to end racial oppression (Cross, 1991). The cross (1991) model is the basis for racial identity development in this study as it is the most widely studied, and a scale has been developed to operationalize and measure the attitudes (Parham \& Helms, 1981).

Racial identity attitudes of college students and adults have been found to be correlated with psychological 
functioning, self-esteem, self-actualization, affective states, and ego development (Parham \& Helms, 1985a, 1985b; Carter, 1991). Preencounter and immersion/emersion attitudes were negatively correlated with self-esteem while encounter and internalization attitudes are positively correlated with self-esteem. Similarly, preencounter and immersion/emersion attitudes were found to be correlated with lower states of self-actualization and negative affective states, especially anger in the immersion/emersion stage. Encounter attitudes were significantly correlated with self-actualization and positive affective states, and internalization attitudes showed similar correlations that were not significant (Parham \& Helms, 1985a; 1985b). Preencounter attitudes were found to be significantly related to anxiety, memory impairment, paranoia, hallucination, alcohol concerns, and global psychological distress (Carter, 1991). Preencounter attitudes as well as immersion/emersion attitudes seem to be related to less healthy psychological functioning while encounter and internalization attitudes were related to positive psychological functioning.

In general, the Black racial identity models begin with a stage in which individuals hold little or no salience to their race or racial issues. Individuals move to the next stage by having an encounter, either a negative racial experience or a positive experience with a member of their 
own race. The experience usually causes dissonance for the individual as their old values and beliefs about race and their personal identity are challenged. This stage is usually accompanied by feelings of anger and confusion. The encounter serves as impetus for individuals to move into the next stage in which individuals learn more about their own race and cultural issues by immersing themselves into their culture. The immersion stage is accompanied by feelings of anger and guilt. The final stage is characterized by individuals integrating values for both their race/ethnicity and the majority culture. The stages have been linked empirically with self-esteem and psychological functioning. Although the Black racial identity models have similar features, several criticisms of the models can be made, particularly on the Cross $(1971,1991)$ model and extensions (Parham, 1989). First, the Cross (1971) model was developed as a reaction to changes made within individuals as a result of the Civil Rights movement within the 1960's. Racial identity development, therefore seems to occur due to external environmental factors. However, Afrocentric psychologists indicate the Black identity is biogenetically determined and not based on environment (Akbar, 1989; Nobles, 1989). There is some concern that Black identity occurs from negative experiences with the environment, and that some the developmental process that begins with a negative experience does not allow the person to fully 
develop an Afrocentric sense of self (Smith, 1989; Akbar, 1989). The model of psychological nigrescence has been criticized because it does not include issues of spirituality within the individual's development (Akbar, 1989; Nobles, 1989). Finally, the model does not address developmental issues as racial identity development was postulated as a linear process. Parham (1989) has suggested that individuals cycle between the stages and that behaviors and tasks in racial identity development differ according to life stages. However, research has not been conducted to determine differences in racial identity development according to developmental life changes.

Helms (1989) has addressed some of the criticism to the psychological nigrescence model. She states that if Black identity is biogenetically predetermined, then individual identity would be fixed. Individuals may have a predisposition to Black racial identity which may be enhanced through socialization. Black identity models are more useful than African identity models as Black identity models address socialization experiences that include survival through racism and the history of slavery within America. Because the experience of Blacks living within this country is different than the experience of Blacks in Africa or other countries (Jamaica, Haiti, etc.), a model addressing changes within the individual due to racism and oppression seem appropriate. 
There has been little empirical research that examines the types of experiences or influences that cause people to move from one stage to the next. Future research needs to focus on specific racial incidents, as well as the influence of parents, peers, the media and/or society. Is the process of racial identity different if the encounter is a negative racial experience or a positive encounter with a member of the same race? Finally, research should determine if the racial identity development process is a one-time linear event, or if individuals "cycle" through the stages throughout the lifespan as has been suggested by Parham (1989).

\section{Racial Identity of Children and Adolescents}

Studies seem to indicate that racial identity development and exploration of racial issues begins in childhood. Studies examining aspects of racial identity in children often focus on one of three aspects of identity, namely, awareness, self-identification, and racial attitudes, but very few examine racial behaviors. Research on self-identification has shown that children as young as three years of age are aware of racial differences and can categorize themselves according to their race (Alejandro-Wright, 1985; Branch \& Newcombe, 1980; Aboud, 1987). Alejandro-Wright (1985) studied the racial classification skills of young children using pictures of Black, White, and Chinese children and developed a four- 
stage model of racial classification from the results. Children were asked to group the pictures according to race and gender. In stage 0 , color, which corresponds to ages three and four years, children simply group people according to skin color, placing light-skinned or dark-skinned individuals in the same category regardless of race. Stage I, subliminal, occurs between four and six years. At this stage, children can distinguish global skin colors by sorting light- and dark-skinned individuals from the same race into the same racial category. At ages six to eight years, children enter stage II, preconceptual, in which racial classification includes physical characteristics beyond skin color. In Stage III, conceptual, children understand physical and biological characteristics as well as the formation of understanding the social factors of race (Alejandro-Wright, 1985).

Although children can categorize themselves according to race correctly by three years of age, they do not believe in the permanence of race until they are seven years old and young children believe that they can choose to be White or Black (Aboud, 1987; Ramsey, 1987). During early adolescence, children understand social implications of race and recognize that they can choose to engage in behaviors or activities that are reflective of their race (AlejandroWright, 1985; Phinney \& Rotheram, 1987).

Research has also focused on racial attitudes, or 
values that children place on race. However, these studies usually address racial preference and not the salience or importance of race. African-American children are typically given photographs of people of various racial groups or dolls representing various racial groups and asked to determine which of the individuals are more attractive, which are nicer, with whom they would chose to be friends, and which child behaves the best. The early research on racial attitudes began with the clark and clark (1939) study. They showed White and Black dolls to preschool age children and asked the children to chose between the dolls. The children frequently chose the white dolls as being the prettiest and the dolls with whom they would like to be friends. The researchers concluded that African-American children have negative self-concepts as they seemed to show a preference for the white dolls (Clark \& Clark, 1939).

Additional research was conducted due to the negative implications from the Clark (1939) studies that AfricanAmerican children may have low self-esteem and poor selfconcept. However, similar results were found by other researchers. Roberts, Mosley, and Chamberlain (1975) studied racial identity and found age differences in young girls using the clark doll method. They found that younger children, ages three to four years, chose white dolls to be the prettiest, although they equally chose both the White and Black doll as resembling them. Hopson and Hopson (1990) 
replicated the clark study and found that the majority of the children studied selected white dolls as being the prettiest and a majority of the children reported that the Black dolls "looked bad".

Branch and Newcombe (1980) hypothesized that the results would be different after the Civil Rights movement and increased racial awareness in this country. They replicated the clark (1939) studies and found that children ages three to five years whose parents were more active in the Civil Rights movement were more likely to choose the White dolls. This finding was discrepant with the common sense notion that parents active in the civil rights movement would raise more Afrocentric children with preferences towards Black dolls. However, Branch and Newcombe's (1980) findings were consistent with the results of other studies examining young children. For instance, Spencer (1982a) found that children around three years of age have Eurocentric values in that they will chose white dolls or photographs featuring white children. McAdoo (1985) studied preschool children to determine if their racial preferences could be modified by offering positive and negative reinforcement for choosing Black dolls. He found that children exhibited a random pattern of selecting the dolls, and that they were not affected by reinforcement. McAdoo (1985) concluded that selection of dolls may indicate neither a white racial preference nor self-hatred 
because of the random selection of dolls. He also recommended that future studies examine the modification of racial attitudes, especially as white preference in doll selection may impact negative identity formation and low self-esteem (McAdoo, 1985).

By the time African-American children reach school-age, their racial preferences seem to change. According to Roberts, Mosley, and Chamberlain (1975), older AfricanAmerican girls, ages six and seven years, chose the Black dolls as resembling themselves and as the prettiest dolls. The researchers indicated that racial identity or positive self-concept may be developmental as the older girls chose the Black dolls (Roberts, et al., 1975). Spencer (1982b) also found that African-American children around nine years exhibit Afrocentric values in choosing Black dolls more frequently. According to the empirical literature, racial attitudes as measured by racial preference seem to have a developmental quality as preschool age Black children tend to have a white preference which seems to change to a Black preference.

Several criticisms can be made of the literature. First, the original clark (1939) study concluded that African-American children have low self-esteem because of their white preferences. However, the only children studied were preschool age children who do not have a solid understanding of racial issues. Cross $(1987,1985)$ has 
criticized the research on racial preferences with children as the studies only measured preference and did not include measures of self-esteem or self-concept. It is possible for the children to have white preferences but have positive self-esteem (Phinney, 1991). The studies also made the assumption that children only use skin color as a criteria for race, as opposed to the use of other features such as hair color and texture, and language (Aboud, 1987). It is also possible that the children's selection of white dolls only reflected society's standards. Aboud (1987) criticized the methodology of the research in that the dolls or pictures may not accurately represent racial groups. Another methodological criticism is that forced choice questions may not accurately reflect the children's perceptions (Ramsey, 1987).

Adolescence is the period in which decisions are made about school achievement, career goals, and interpersonal relationships. For racial minority adolescents, cultural factors must be included as adolescents are faced with societal pressures to identify with their particular racial or ethnic group (Spencer, et al., 1991; Fordham, 1988; Gay, 1978). Pressures around racial identity differ for adolescents than for younger children. All adolescents must decide on career goals and achievement in school, but according to some researchers, African-American adolescents face the pressure of being seen as abandoning their culture 
or "acting white" when they are high achievers in school (Fordham, 1988; Ford-Harris, Schuerger, \& Harris, 1991; Hopson \& Hopson, 1990). Additionally, some career channels may seem closed to African-American adolescents due to discrimination and/or lack of opportunities and role models. Research on adolescents indicate that adolescents explore their racial identity. Studies conducted with adolescents have also indicated that adolescents may experience several stages of racial identity development as outlined by the racial identity models (Aries \& Moorehead, 1989; Ward, 1990). One study examined racial identity in school-age children and adolescents, and found that there were changes in racial identity across age groups (Banks, 1984). According to Banks (1984), adolescent girls seem to have less pro-Black attitudes and feelings, especially in judging physical aspects such as beauty. Phinney (1989) also interviewed ninety-one adolescents and found that they were exploring racial issues. Girls were concerned with physical beauty and boys were worried about discrimination (Phinney, 1989). Cummings and Carrere (1975) found no differences in racial identity attitudes and the level of self-esteem in adolescents or differences according to social economic status. Aries \& Moorehead (1989) measured adolescents and found that all had made some commitment to formulating a racial identity and integrating it with their personal identity. 
Phinney and Tarver (1988) examined racial attitudes of early adolescents between the ages of twelve and fourteen years by giving them a qualitative interview schedule that addressed the importance of race and racial incidents. A number of the children indicated that they were aware of racism, had thought about how their race will influence their future, and could list positive and negative aspects of their race (Phinney and Tarver, 1988). Ward (1990) interviewed seven high achieving African-American adolescents to explore the formulation of racial identity. According to their own report, the students at the school entered with preencounter attitudes according to the cross (1971) model, but by their junior year had become more involved with African-American activities and had moved into Cross' immersion or internalization stages (Ward, 1990). These two studies are important because of the qualitative methodology that allowed children to directly report racial experiences and the salience of racial issues which may more accurately reflect attitudes.

In summary, adolescents explore racial issues and begin to examine their own identity. Qualitative research on the racial identity development of adolescents suggests that African-American adolescents move through the stages postulated in racial identity models. Adolescents indicate that they have begun to explore racial issues and to understand how it impacts their lives, including 
experiencing racism and oppression, and physical beauty. Parham (1989) suggested that racial identity development begins in adolescence, and that individuals "recycle" through stages across the lifespan resolving different tasks according to developmental issues. The research on adolescents seems to support this notion.

The research methodology utilized with adolescents varies, but the use of qualitative measures, including interviews and open-ended questionnaires has allowed adolescents to explore and describe their attitudes in much greater detail. Future research should examine the racial identity development of adolescents using a variety of research methodologies. Studies should ascertain if tasks for racial identity development in adolescents correlate with their life-cycle developmental tasks, including formulation of identity, achievement and career concerns, and dating issues.

The research on both children and adolescents indicate that they are aware of racial issues and the impact of race on their lives. Adolescents in particular seem to actively work at developing their racial identity. The research has found that racial identity development and attitudes seem to follow a developmental path with children moving from categorizing race to understanding the impact that race has on their lives. However, the factors that influence the development have remained relatively unexamined. 
Parental Influences on Racial Identity Attitudes

In general, socialization has been defined as the preparation of children to accept adult roles and responsibilities in society through the teaching and learning of conventional beliefs, values, and patterns of behavior (Boykin \& Toms, 1985). This is done through both overt messages as well as the implicit learning of values through observation of the style and patterns of behaviors and manners of relating interpersonally (Greene, 1992a). Socialization serves as preparation for the development of gender roles, behaviors for the school and work place, as well as roles within the family. It occurs through peers, the school system, churches and other social organizations, and through the media. The role of mass media and communication is very influential. However, the most important source of socialization, especially for preschool and primary grade children, is the parents (Demo \& Hughes, 1990; MCAdoo, 1985; Harrison, 1985; Spencer, et al., 1988). When the child enters the school system, the role of socialization from individuals other than family members increases. Parents today are faced with greater pressure to prepare their children for success within society as children face negative peer pressure to not achieve in school, to use drugs, and to engage in premarital sexual intercourse.

Typically, the family is the primary socializing agent, 
and is supported by the school and judicial systems, and the media (Boykin \& Toms, 1985). African-American parents are often not supported by the media, school, or judicial systems. They face heightened pressure as they must counter negative messages from the media, and face oppression, racism, discrimination, and covert and overt prejudice (Peters, 1985). African-American parents must not only teach their children how to be productive members of society, but how to survive in a racist one (Stevenson, 1993; Peters, 1985; Parham, 1993).

Racial socialization has been defined as raising children to be physically and emotionally healthy in an environment of extreme stress in which being AfricanAmerican is perceived as negative by the dominant society (Peters, 1985). Greene (1992a) defined racial socialization as the legacy of skills which are explicitly and implicitly passed down to children through parents and extended family members to deflect and negotiate a hostile environment. Similarly, stevenson (1993) defined racial socialization as the process of helping children integrate a sense of self in a hostile environment. All of the definitions indicate the importance of teaching African-American children coping strategies to live productively and to develop a positive self-concept within an oppressive society.

In order for parents to socialize children, they must be clear about their own racial beliefs, and have specified 
strategies for dealing with racism (Parham, 1993; Hopson \& Hopson, 1990). It is important for parents to discuss racial issues with their children as children may experience negative encounters (Spencer, 1990). Early negative encounters are often what causes a child to realize that they are African-American and that the dominant society perceives being African-American as negative. Parents must socialize children in a way that does not overwhelm children, lead children to experience paranoia and discomfort, or in a way that is not overly protective (Greene, 1992a). They must provide a buffer for negative messages received from society, and serve as translators of messages and experiences with mixed racial and ethnic groups (Greene, 1992a; Harrison, 1985). Some parents do not socialize their children to racial issues because they feel that the issues are not important or they hope that their children will not have to experience racism (Hopson \& Hopson, 1990). Others feel that it will cause their children to become bitter and resentful of Whites, while some parents will only discuss racial issues if their children initiate the discussions (Sanders Thompson, 1994; MCAdOO, 1985)

Racial socialization styles and methods can be categorized according to two conceptual models. Boykin and Toms (1985) classify families into three categories according to the type of messages transmitted. African- 
American families that are classified as mainstream generally socialize their children according to Eurocentric values and beliefs. Mainstream families tend to run into problems as parents may espouse Eurocentric values, but demonstrate more Afrocentric values through their behavior. Families can also be classified as having a minority socializing orientation. This orientation includes passively accepting oppressive and racist beliefs and trying to work within the racist society. The third classification is Black cultural. In this orientation, parents transmit Afrocentric values according to West African traditions. The authors outline nine dimensions that are transmitted by Black cultural families. These dimensions include the importance of spirituality, and harmony, movement, verve, affect, communalism, expressive individualism, orality, and social time perspective.

Bowman and Howard (1985) and Sanders Thompson (1994) categorized socialization messages into four areas based on research findings. These categories include racial identity, self-development, racial barriers, and egalitarian views. Racial identity messages focus on racial pride, African heritage, and familial and cultural history. Messages on self-development include the importance of education and achievement, and the importance of hard work. Racial barriers messages provide an awareness of racism and prejudice, and treating others fairly, despite not being 
treated fairly by whites. Egalitarian messages focus on human universals and do not emphasize racial differences (Sanders Thompsor, 1994; Bowman and Howard, 1985).

Studies have examined the influence of parental racial socialization practices. Branch and Newcombe (1986) asked parents about racial socialization attitudes and the importance of teaching racial messages to children by assessing racial socialization attitudes and Afrocentric attitudes. The researchers found that six to seven year old children whose parents indicated the importance of racial socialization tended to choose the Black dolls in the doll tests. This finding may indicate the importance of parental messages on racial preferences or that the children may have simply reached the developmental stage of Black preferences. Spencer (1983) found that school-age children whose parents knew a great deal about Black history generally had more Afrocentric values. It was not determined, however, if the parents taught the children Black history and if this had an influence on their identity. These two studies suggest that parents who feel that racial socialization is important and have knowledge about African heritage and history tend to have school-age children with more Afrocentric beliefs as measured by the dolls. However, it is unclear if the children chose the Black dolls due to developmental change or to the racial socialization practices of the parents. Branch and Newcombe's (1980) earlier study indicated that 
preschool children's preferences for Black dolls were not affected by their parent's participation in civil rights activities. When directly asked, parents indicated that they do not teach their children racial messages (Spencer, 1990). Future studies should determine the importance or significance that parents attribute to racial socialization as well as determine specific racial messages that are taught.

Barnes (1991) attempted to directly measure parental influence on children's beliefs by studying young children and their parents. Parents with higher income levels felt more strongly that Black history should be taught to their children. Parents who indicated a high level of political activity had children with positive racial identity as indicated by positive evaluation of their racial group and friendship choices. Similarly, children scored higher on a measure of racial identity if their parents tended to blame the system and endorsed militant actions (Barnes, 1991).

Bowman and Howard (1985) studied 377 adolescents through qualitative measures asking about the messages that parents give them on racial issues. A majority of the adolescents reported that their parents did not tend to give them racial socialization messages, with a significant difference in the number of girls reporting receiving no messages than boys ( $41 \%$ vs. $36 \%$, respectively). Of the adolescents that received messages, boys reported that they 
were often taught about racial barriers and egalitarianism. When girls were given messages, they were taught racial pride. School achievement and self-efficacy were also measured and it was found that children who were not taught messages had lower self-efficacy. Furthermore, it was found that children who were taught messages had higher grades (Bowman \& Howard, 1985).

Research has directly examined parents' beliefs on racial socialization. Spencer (1990) interviewed forty-five parents of preschool and school-age children and found that the parents did not teach children racial pride although most of them emphasized personal values and morals. She also found that the parents reported that they did not do anything if their children reported racial incidents (Spencer, 1990). This approach by parents may leave children with no resources to explore racial identity attitudes or questions. Thornton, Chatters, Taylor, and Allen (1990) in a national survey asked over 2,000 parents of adolescents about racial messages. The majority of the parents. (64\%) stated that they did socialize their children by giving them messages about racial issues, and parents with higher levels of education and older parents tended to report that they socialized their children more. The messages that they tended to give children focused on achieving and working hard, being a good citizen, racial pride, Black heritage, the importance of recognizing and 
accepting their racial background, oppression, and racism (Thornton, et al., 1990). The results of these two studies may differ as the age of children varied, and may also indicate that parents of adolescents feel more strongly about racial socialization.

Peters (1985) interviewed 16 parents on their childrearing beliefs and racial experiences. Many of the parents reported that it is important to racially socialize their children. They reported teaching survival skills for prejudice and discrimination, self-pride, positive selfconcept, and self-respect. Parents also indicated the importance of teaching racial pride, heritage, and the importance of education. They also provided egalitarian messages, including that their children are equal to whites, but reported warning children that they may experience oppression and may not be treated fairly by whites. Some of the parents stated that they had faced discrimination with their children, such as not being served in restaurants, and were confused as to how to explain the issue with their children. The parents gave mixed responses when asked if being Black was an added burden for their children. Nine indicated that being Black is a burden, but others felt that it is only a burden if the parents felt stressed. Almost all of the parents indicated, however, that being Black is a stressor for them as parents. Also, most of the parents reported that they felt inadequately prepared by their own 
parents to deal with racial issues (Peters, 1985). The studies that directly measure parents indicate that parents feel that it is important to racially socialize their children. Specific messages include the reality of racism and oppression, racial pride, self-pride, and the importance of achievement and education.

There have been some investigations utilizing a retrospective design of asking adults to recollect their own socialization experiences as children. Parham and williams (1993) asked 114 adults ages 18-68 years about messages they had been given as children from their parents. Half of the sample reported that they received neutral or negative messages about their race and $20 \%$ reported that they received no messages. The adults who did receive messages reported the following messages: feel proud of their race, to feel pride but not to show it, the importance of being human and not Black, and to not be proud to be Black (Parham \& Williams, 1993). In a similar study, Sanders Thompson (1994) surveyed 225 adults ages of eighteen to eighty-five years on their recollections about sócialization experiences with their parents and extended family members. Only 50\% indicated that the discussions with their parents focused on racial socialization, defined by race-related discussions including oppression and coping strategies, whereas $71 \%$ reported racial socialization conversations with other family members. The participants who indicated that they 
were racially socialized reported receiving advice on coping with racial barriers. Adults under 36 years of age reported receiving messages on racial pride, while older adults indicated that they had received self-development and egalitarian messages (Sanders Thompson, 1994).

It is important to note that the results of the retrospective studies differ significantly from direct studies of parents. Retrospective studies tend to find that not all parents racially socialize their children, and that parents tend to give neutral messages or no messages about race. Direct studies tend to find that the large majority of parents racially socialize their children and feel that racial socialization is important. Parents when studied directly indicate that they teach children specific messages, such as racial pride, self-pride, and the importance of education. The findings from parents examined directly suggest that African-American parents who feel that socialization is important may actively socialize their children by teaching them specific messages.

Some important methodological considerations could explain these conflicting results. The studies that ask for recollections include a wide age range of participants, from early adolescents to senior citizens. A critical oversight and a threat of invalidity has to do with potential cohort effects. The research does not ascertain differences that may exist in racial socialization experiences according to 
cohorts. Adults who were raised during the civil Rights movement may have been taught racial messages, including the importance of racial pride. Older adults in the studies may have been taught to not emphasize their race, and parents of adolescents in the studies may have felt it unimportant to racially socialize their children due to changes within society. The participants in these studies may not have remembered racial discussions with their parents, and may have assumed that the parents did not discuss race. The retrospective studies also did not determine implicit racial socialization messages received by participants.

The research on racial socialization seems incomplete as many issues and concerns have not been studied. Because of the possible invalidity of retrospective studies, the importance of racial socialization and the percentage of parents who teach children racial messages remains unclear. Additionally, research suggests that approximately one-third of the parents measured directly report that they do not socialize their children. One-half of adults in retrospective studies indicate that they were not socialized directly by their parents, although these results must be interpreted cautiously. The research has not determined why this small percentage of parents feel that it is not important to socialize their children. Parents may not discuss race with their children because they do not know how to discuss issues, or they may feel that a discussion of 
racism may upset their children. Others may feel that the social climate of the country has changed and that there is not a need to discuss race. Other parents may feel that implicit racial messages, such as participation in civil Rights or political activities, participation in cultural activities, and teaching children Black history are more influential than direct discussions.

Racial socialization research has also not focused on factors that influence racial socialization attitudes. Studies indicate that parents with higher educational levels and with higher socioeconomic status may be more likely to racially socialize children. Additionally, research has not examined differences in socialization attitudes according to gender of the children. More importantly, only one study has attempted to understand the impact of the parent's racial identity or Afrocentric attitudes on racial socialization attitudes. Future research should focus specifically on verbal messages and indirect methods of socialization, the importance of culture and history, parents' comfort level in discussing racial issues, differences in socialization for girls and boys, and differences across age ranges. 


\section{CHAPTER III}

METHODOLOGY

\section{Participants}

Participants were selected from three African-American churches in two mid-Southern cities within the same state. Two of the churches were Baptist, and one church was Methodist in denomination. Two hundred thirty individuals were invited to participate in the study, which included abut 175 households of both single-parent and two parent families. Potential participants were selected from the various church directories and through the ministers, and were invited to participate in the study if they were listed as parent(s), grandparent(s) with legal and physical custody, or stepparent of at least one child. Completed surveys were received from 107 individuals. Two surveys were excluded as the entire set of instruments were not completed, and one was excluded as the participant indicated that he had no children. Therefore, 104 subjects participated in the study, yielding a response rate of $44 \%$ of individuals and $59 \%$ of households. Forty-two (40\%) sets of surveys were received from church one, forty-six (44z) sets were received from Church two, and seventeen (16\%) sets were received from Church three. 
Thirty-five men $(34 \%)$ and 69 women (66\%) completed surveys. The age range of subjects was 17 to 76 years of age, with a mean age of 42 years (S.D.=9.473). The mean age for men was 41 years, and for women, the mean age was 41 years. The majority of the participants reported that they were married $(73 \%)$. Approximately $14 \%$ reported that they were single or never married, and $14 \%$ reported that they were divorced or widowed. Most of the participants reported incomes of $\$ 20,000$ or more. Only $11 \%$ reported incomes of less than $\$ 20,000$. Approximately $45 \%$ reported middle level income between $\$ 20,000$ and $\$ 49,999$. About $44 \%$ of participants reported an income level of $\$ 50,000$ or more. Six participants did not indicate their income level. All of the participants had at least a high school diploma. Twenty-two percent of the subjects had at least some college experience, while approximately $20 \%$ reported receiving college degrees. About $27 \%$ reported completing some graduate school courses or receiving graduate degrees. Table 1 lists marital status, income levels, and educational levels for men and women. 
Table 1

Demographic Frequencies According to Gender

$$
\text { Males Females Total }
$$

Marital status

$\begin{array}{lrrrrr}\text { Single } & 4 & (11.4 \%) & 10(14.5 \%) & 14 & (13.5 \%) \\ \text { Married } & 29 & (82.9 \%) & 47(68.1 \%) & 76 & (72.3 \%) \\ \text { Divorced/widowed } & 2 & (5.7 \%) & 12(17.4 \%) & 14(13.5 \%)\end{array}$

Income Level*

$\begin{array}{lrlrlll}\text { Below } \$ 20,000 & 3 & (8.6 \%) & 8 & (11.6 \%) & 11 & (11.2 \%) \\ \$ 20,000-\$ 49,999 & 10 & (28.6 \%) & 34 & (49.3 \%) & 44 & (44.9 \%) \\ \$ 50,000 \text { or more } & 19(54.2 \%) & 24(34.8 \%) & 43(43.9 \%)\end{array}$

Educational Level**

$\begin{array}{lrlllll}\text { High School } & 6(17.1 \%) & 15(21.7 \%) & 21 & (21.2 \%) \\ \text { College Degree } & 9(25.7 \%) & 11 & (15.9 \%) & 20 & (20.0 \%) \\ \text { Graduate School } & 15(42.9 \%) & 20 & (29.0 \%) & 35(35.0 \%)\end{array}$

* 6 missing cases. ** 5 missing cases.

Generally, the sample included married, middle-class individuals from the mid-South who had completed some college courses. The sample may not be representative of all African-American parents, but may represent middle-class African-American parents that live in the mid-South region of the country.

\section{Measures}

Racial and Social Awareness Subscale of the Black Parental Attitude Scale. The Black Parental Attitude Scale (BPA) ia a 76-item scale that measures a variety of factors related to parenting and childrearing attitudes (Johnson, 
1980). The racial and social awareness subscale is a seventeen item subscale that measures the importance of racial socialization and specific messages. The subscale was primarily used to provide empirical information on parental messages and beliefs on teaching children about racial issues. The BPA was developed by a panel of judges. Categories and items were generated by judges after inspecting the literature on African-American childrearing practices. The items are written using a five-point Likert-like scale. Respondents are asked to rate the extent of agreement with statements, (categories include strongly disagree, disagree, undecided, agree, strongly agree). High scores on the racial and social awareness subscale indicate that positive attitudes towards teaching children pro-Black messages, and low scores indicate a less favorable attitude towards teaching children pro-Black messages. Test-retest reliability coefficient for the racial and social awareness subscale was found to be .69 , and the internal consistency coefficient alpha for the subscale was .63 , indicating moderate reliability (Johnson, 1980). The BPA was found to be positively correlated $(r=.64, p<.001)$ with the Black Ethnocentrism Scale, a scale that measures ethnocentrism, including pro-Black and anti-White attitudes, indicating convergent validity. A copy of the BPA is included in Appendix A.

Racial Identity Attitude Scale. The Racial Identity 
Attitude Scale (RIAS) (Parham \& Helms, 1981) is a 30-item scale that measures attitudes associated with the cross (1971) model of racial identity development. This instrument was utilized to determine racial identity attitudes of the parents. The scale was designed using Hall, Cross, and Freedle's (1972) Q-sort procedure which asked subjects to sort cards that reflected attitudes at various stages. The RIAS uses a Likert scale ( 1 = "strongly disagree" and 5= "strongly agree") and subjects are asked to rate each item based on the extent of their agreement. Scores are obtained by summing the responses for each stage and dividing by the number of items in each subscale. A copy of the scale is included on Appendix B.

Internal consistency reliability for the subscales are: Preencounter, .67; Encounter, .72; Immersion/Emersion, .66; Internalization, .71 (Parham \& Helms, 1981). Ponterotto and Wise (1987) found strong support for the preencounter, immersion, and internalization subscales using oblique factor analytic methods and examining alternative factor solutions, accounting for $36.1 \%$ of the variance before rotation, and $26.7 \%$ of the variance after rotation. In addition, they found high subscale intercorrelations which indicated that the four subscales may not be independent. However, the scale has been revised by changing the wording of questions to more closely match the attitudes postulated in the model in order to address these issues. validity 
evidence for the RIAS has been consistently found. Racial identity attitudes have predicted various preference for counselors (Parham \& Helms, 1981), emotional states and psychological functioning (Parham \& Helms, 1985a, 1985b; Carter, 1991).

Qualitative Racial Attitude Measure for Parents. An open-ended questionnaire was also given to the parents, and was included to gather specific information on racial socialization, and to determine the nature of explicit messages given to children. The questionnaire asked demographic information and four open-ended questions about racial messages. The first question asks if parents believe it is important to teach children racial issues, and the reasons why. The second question asks for specific messages parents teach to their children. The final two questions ask for messages taught according to gender. Questions were developed by the examiner and were revised with a committee of three faculty members. A pilot sample of 10 individuals between the ages of 25 and 40 years were given the questions to determine if the wording and phrasing elicited the desired information. A copy of the survey is included in Appendix $\mathrm{C}$.

\section{Procedures}

For the initial church sample, parents were alerted of the research study through announcements at church, listings in the church bulletins, and through an introductory letter. 
A copy of the introductory letter is included in Appendix D. Parents were also invited to participate in parenting workshops with the researcher in order to encourage completion of the surveys. Attendance in the workshops was not mandatory for participation in the study. Parents were invited to participate in the study through letters in the mail, and were asked to return surveys to the church office, church library, or to mail them to the researcher. The letter explained that the study included the one-time completion of surveys, and that responses would be confidential and reported anonymously. Follow-up postcards were sent after two weeks. After four weeks, a new set of instruments was sent to participants along with a postage paid envelope for which to return surveys. Parents from the additional two churches were invited to participate through their minister and members of the church. Parents were identified and given introductory letters, surveys, and a return envelope.

\section{Statistical Analysis}

The quantitative data was analyzed using a variety of statistical procedures. Analysis of variance tests (ANOVAs) were computed to determine if differences occurred in demographic variables according to location. ANOVAs were computed to determine if differences occurred in racial identity and racial socialization attitudes on the RIAS and the BPA subscale according to gender, socioeconomic status, 
educational level and marital status of the parents. Multiple regression equations were computed using the subscales of the RIAS as independent variables and the racial and social awareness subscale as the dependent variable. Qualitative information from the parental survey was analyzed through open coding to determine categories of responses. Frequencies were tallied within categories of responses for each question.

\section{Research Hypotheses}

$\mathrm{H}_{1}$ : Parents with strong preencounter attitudes will feel that it is not important to present racial messages to their children as they may have pro-White and anti-Black attitudes. Regression analysis will yield a significant negative relationship between the preencounter and the racial and social awareness subscales.

$\mathrm{H}_{2}$ : Parents with strong encounter attitudes will be experiencing confusion, hurt and anger, and may feel ambivalent about presenting racial messages. Multiple regression analysis will not yield a significant relationship between the encounter and the social and racial awareness subscales.

$\mathrm{H}_{3}$ : Parents with strong immersion/emersion attitudes will feel that it is extremely important to teach children racial and cultural issues, and may teach their children to mistrust and hate Whites. Multiple regression analysis will yield a significant positive relationship between the 
immersion/emersion and the social and racial subscales. $\mathrm{H}_{4}$ : Parents with strong internalization attitudes will feel that it is important to teach racial issues to children, but will not feel or express anger or a lack of trust towards Whites. Multiple regression analysis will not yield a significant relationship between internalization and racial and social awareness subscales. $\mathrm{H}_{5}$ : Parents will give a variety of messages to children, including the importance of history, understanding racism and oppression, and the importance of striving for achievement.

$\mathrm{H}_{6}$ : Boys will receive messages around school achievement, and racial barriers and oppression.

$\mathrm{H}_{7}$ : Girls will receive messages on racial pride and sexuality. 


\section{CHAPTER IV}

\section{RESULTS}

This chapter presents the results of the analyses regarding the research hypotheses from the research questions. The study was designed to determine the relationship among racial identity attitudes and childrearing beliefs, specifically beliefs around racial socialization, and included quantitative and qualitative measures. There were four hypotheses regarding the relationship among racial identity attitudes as measured by the RIAS. It was hypothesized that strong encounter attitudes would yield a significant negative relationship with racial socialization attitudes, and that encounter attitudes would not relate significantly to racial socialization attitudes. It was also hypothesized that immersion attitudes would yield a significant positive relationship with racial socialization attitudes, and that internalization attitudes would not significantly predict racial socialization attitudes.

The study also predicted that parents would feel that it is important to socialize children to racial issues. Based upon previous research, it was hypothesized that parents would teach children a variety of messages, 
including the importance of history, understanding racism and oppression, and the importance of striving for achievement. Specific messages to boys would include importance of school achievement, and overcoming racial barriers and oppression, while specific messages to girls would include racial pride.

The analysis was conducted in several phases. The first analysis determined differences according to the location of the participants. The next phase included scoring the RIAS and the BPA and determining differences in attitudes according to demographic factors through analysis of variance. Then, multiple regression was conducted to determine the relationship between the predictor variables of the racial identity attitudes and the criterion variable of the racial socialization attitudes. The qualitative surveys were scored according to open coding in order to determine the importance of racial socialization, and specific messages given according to gender.

\section{Quantitative Results}

The first phase of the analysis was to determine if differences existed on demographic variables according to location for data collection. One-way analysis of variance tests were conducted to ascertain significant differences according to gender, socioeconomic status, educational level, and marital status. No significant differences were found for marital status or educational level. significant 
differences were found for gender across locations, $\mathrm{F}(2,102)=8.19, \mathrm{p}<.001$. Tukey's HSD post-hoc test indicated that the number of men and women differed across the three locations, indicating that the second church had fewer female participants. Significant differences in location were also found according to socioeconomic status, $F(2,96)=6.327, p<.003$. Tukey's HSD post-hoc test $[Q(96)=10.343, p<.05]$ indicated participants from church 1 $(\mathrm{m}=2.537, \mathrm{s.d} .=.552)$ reported a significantly higher income level than Church $3(m=1.875, s . d .=.619)$. Both means suggest, however, that the majority of the participants fell within the middle income range. As the differences according to location were few and were not the variables hypothesized to be related to racial identity or racial socialization attitudes, the locations were grouped together for further analysis.

The second phase of analysis sought to examine differences in racial identity and racial socialization attitudes according to gender, marital status, educational level, and socioeconomic status. Table 2 lists the mean scores of racial identity attitudes and the racial socialization subscale of the BPA. The mean scores indicate that internalization attitudes were stronger for these participants than preencounter, encounter, or immersion attitudes. The standard deviations also suggest that the variation of scores is small. 
Table 2

Mean Scores for Racial Identity and Socialization Attitudes

$\begin{array}{lcc}\text { Variables } & \text { Means } & \text { Standard Deviation } \\ \text { Preencounter } & 2.009 & .419 \\ \text { Encounter } & 2.799 & .681 \\ \text { Immersion } & 2.410 & .504 \\ \text { Internalization } & 4.026 & .479 \\ \text { Race Socialization } & 3.860 & .320\end{array}$

For this study, internal consistency coefficient alpha's for the subscales were: Preencounter, .49; Encounter, .51; Immersion/Emersion, .50; Internalization, .64. The internal consistency coefficient alpha for the racial and social dwareness subscale was .57 , suggesting moderate reliability. Table 3 lists the internal consistency coefficient alpha and the intercorrelations for each scale. 
Table 3

Correlation coefficients for RIAS subscales and BPA Subscale

\begin{tabular}{|c|c|c|c|c|}
\hline & Enc & Imm & Int & Rac \\
\hline Pre & $.274 *$ & .202 & $-.380 *$ & $-.238 *$ \\
\hline Enc & & $.657 \star$ & $.381 *$ & $.211 *$ \\
\hline Imm & & & $.269 \star$ & .060 \\
\hline Int & & & & $.438 *$ \\
\hline
\end{tabular}

Note: Pre=Preencounter, Enc=Encounter, Imm=Immersion, Int=Internalization, Rac=Racial/social awareness $\star p<.01$

The intercorrelations suggest that preencounter scores are negatively related to the racial and social awareness subscale, encounter scores are significantly positively related to the racial and social awareness subscale, and that internalization scores are significantly positively related to the racial and social awareness subscale.

One-way ANOVA's were conducted on each of the racial identity attitudes subscales with demographic factors of marital status, educational level, socioeconomic status, and gender as independent variables. No significant differences were found for both preencounter and internalization attitudes. However, educational level was found to be significant for both encounter and immersion attitudes. For 
encounter attitudes, significant differences were found in educational level, $F(2,96)=3.073, p<.05$. Tukey's HSD posthoc test $[Q(98)=6.75, p<.05]$ indicated that participants who had only earned a high school diploma $(m=3.060, s . d .=.720)$ had significantly higher encounter attitudes than participants who had some graduate school experience $(m=2.605, s . d .=.649)$. Similarly, immersion attitudes differed according to educational level. Tukey's HSD post-hoc test $[Q(98)=8.572, p<.05]$ indicated that participants with only high school diplomas $(m=2.657$, s.d.=.574) had significantly higher immersion attitudes than participants with some graduate school coursework $(m=2.254$, s.d.=.435). Participants with just high school degrees had stronger encounter and immersion attitudes than participants with college and graduate school experience.

The third phase of analysis sought to directly examine the research hypotheses relating to the relationship between the independent variables of the racial identity attitudes and racial socialization attitudes. One-way ANOVAs were conducted to determine if differences existed in racial socialization attitudes according to demographic variables of gender, marital status, socioeconomic status, and educational level. There were no significant differences in racial socialization attitudes according to marital status, socioeconomic status, and educational level. Significant differences were found in racial socialization attitudes 
according to gender, however, $F(1,102)=7.226, p<.01$. Women $(m=3.918, s . d .=.323)$ seem to have higher racial socialization attitudes, indicating stronger pro-Black childrearing attitudes than men $(m=3.747$, s.d.=.272).

As racial socialization attitudes were found to differ significantly according to gender, a stepwise multiple regression plot was conducted with gender and age of participants in order to determine the amount of variance within racial socialization scores that can be accounted for by gender and age. Age was included in the regression as it as measured in continuous data and had not been included in a one-way ANOVA. Age did not contribute to the predictor equation, but gender was found to significantly contribute to the equation, $[F(1,97)=5.690, p<.019]$. Five percent of the variability of racial socialization attitudes can be explained by gender.

The independent variables of preencounter, encounter, immersion, and internalization attitudes were entered into a stepwise regression plot in order to test the research hypothesis. These results will first be discussed according to the general findings, and then each hypothesis will be separately addressed. The best predictor model for racial socialization scores only included internalization attitudes. It was hypothesized that internalization attitudes would not contribute significantly to racial socialization attitudes. However, internalization attitudes 
accounted for $19 \%$ of the variance in racial socialization scores $[F(1,102)=24.273, p<.0001]$. Internalization attitudes have a positive relationship with racial socialization attitudes, so as internalization attitudes increase, racial socialization attitudes increase.

It was also hypothesized that preencounter attitudes would yield a significant negative relationship to racial socialization attitudes, and this was not confirmed in the study. The third hypothesis for the study was that encounter attitudes would not relate significantly to racial socialization attitudes, and the results were not related significantly. The final hypothesis was that immersion attitudes would have a positive significant relationship with racial socialization attitudes, and this was not confirmed in the study.

\section{Qualitative Results}

Four open-ended questions were asked of participants in order to determine the importance of racial socialization, to elicit specific messages taught to children and adolescents, as well as messages taught according to gender. The results were content analyzed in order to determine frequencies of responses. Then the responses were clustered into categories which seem to reflect themes in the importance of socialization and types of messages taught.

The questions generated a variety of responses, and most of the parents indicated the difficulty of socializing 
children to racial issues. Many feel that it is inevitable that their children will experience racism, and they would like to prepare their children to confront and cope with racism in the most effective manner. Some parents used the questions as opportunities to express their fears for their children, as well as the anger that they feel about the injustice of racism and oppression. One parent expressed her frustration for her child.

Prime example is my son. He was pulled over by the police 3 times within his first year of driving, because we own nice... vehicles. After the third time the tears in his eyes told me that even though the law says racial discrimination is over, the attitude says it's not. The frustration I saw in his eyes that day about things we could never change (our skin color and people's attitudes) left a scar- an indelible impression.... He has become bitter and somewhat hardened by life. And rightfully so.

The first question was designed to elicit the relative importance that parents attributed to racial socialization. A total of 140 codable responses were given, and an overwhelming majority (96\%) of the parents feel that it is important to teach children about racial issues. Five parents reported that they do not feel it is important to teach racial messages, seemingly because they feel it may have a negative impact on their children. Three parents reported that they would only discuss racial matters if their children initiated the discussion, and one parent indicated that it would negatively impact their children and possibly make them paranoid in dealing with others. One 
parent simply indicated that it is not important.

Parents listed a variety of reasons for feeling that racial socialization is important. Table 4 lists the themes generated from the responses regarding the importance of teaching children racial issues. The primary reason given by parents is the reality and awareness of racism (21\%). Parents felt that being aware of racism is the first step in combating or coping with racism. "Children need to be prepared to face reality. Racism is part of the reality of being Black in today's society." "I believe it is important to teach my children about racial issues because this is a very real part of our society in America." Nine of the parents stated directly that their children would face racism. "Children are confronted with this at an early age if they live in a mixed neighborhood and attend day care centers.", "They will have to face prejudice somewhere in their lives."

Parents are also concerned that their children are prepared to cope with racism (18\% of responses). Parents indicated that children should understand others' motivations and behaviors and that they should know how to protect themselves. Functioning effectively was the third most frequently cited response (11\%), as parents indicated that their children need to be prepared to succeed within society, should value their education, and should be able to compete with their Caucasian counterparts. "Yes, so they 
can be somewhat prepared for things that may happen in life."

Parents also felt that it is important to teach children about racial issues in order to give them a sense of history ( $18 \%$ of responses). "Children need to know their roots." Other reasons included cultural enrichment (6\%), and self-development ( $5 \%$ ). They also felt that teaching children about racial issues could help change racism or change people's attitudes about racism (4\%). Finally, some parents felt that it is an important task for parents over teachers, friends, or others to socialize children to racial issues ( $2 \%)$. "Because of the fact that I am Black, I feel that experience makes me more knowledgeable than maybe a teacher or friend."

The results from this question seem to support the hypothesis that parents feel that racial socialization is important for a variety of reasons. 
Table 4

Categories for Importance of Racial Socialization

Presence of racism

$\frac{\text { Frequency }}{30} \frac{\text { of Total Responses }}{21}$

Racism is part of reality

Children will face racism

Judged by skin color

Importance of awareness

13

Awareness of racism

knowledge of political issues

Sense of History

25

18

Prepare for challenges

Prepare for challenges

Understand others' behaviors

Develop buffers

Protection and safety

Disservice not to prepare

Function effectively

Function effectively

Prepare for success

Importance of education

Be able to compete

Effect's choices in life

Cultural enrichment

Understand diversity

Cultural enrichment

Understand Black culture

Develop racial pride

Perpetuation of culture

Participate in civil rights

Self-development

Positive self-esteem

Personal enrichment

Help change attitudes

Must be parents who teach

Miscellaneous

They are God's children 
The second question elicited specific messages that parents teach in order to socialize children. Parents listed 205 specific messages that are taught to their children. Table 5 lists the categories of specific messages taught to children and adolescents. The results were similar to previous research findings which cite that parents teach messages on racial pride, self-development, achievement, egalitarianism, and cultural enrichment.

Parents in the current study stressed the reality of racism with their children ( $5 \%$ of responses). These messages include that their children will face racism and oppression, that they will be judged by the color of their skin, and that they may be denied opportunities due to their race. " ...to be aware that racist attitudes often causes them to be overlooked in classrooms, board rooms, offices, etc." Parents also teach children coping strategies and methods to overcome racism $(13 \%)$. The responses indicated that children are taught not allow others to use their race against them, and to not use race as an excuse for not achieving. "I also tell them to not rely on the old 'copouts" about the 'man' and the 'system'." "Never let your race be an excuse for not achieving what you want to be." Other parents teach children to handle racism diplomatically, and to learn to deal appropriately with whites. Children are also taught to be strong and to stand up for their rights. 
Most of the messages in the current study emphasize the importance of achievement (26\%), which includes the importance of seeking a good education. "Education is essential for successful living." Parents also stressed that although their children would have to work harder than Whites to achieve or to be recognized, they can achieve anything, especially if they set goals and strive to achieve. "That they have to work twice as hard to be better than the white race. Get an education." "They have to understand that life is more difficuit, because of the racial prejudice in this country, but they will have to work harder to overcome that obstacle."

The second most frequent message was teaching children racial pride (198). Parents want their children to feel proud to be Black, to recognize that they are beautiful individuals, and that being Black is positive. "Be proud! The Black race is a highly spirited, intellectual race." "Be proud of heritage and don't let others make them feel they shouldn't have pride." One parent, however, emphasized that racial pride in the extreme can be dangerous. An additional seven percent of the responses indicated the importance of teaching children African heritage and civil rights history. "I have books on Black inventors and we read books about Martin Luther King and other positive Black people." "Origin and heritage information... basically historical messages." Four percent of the responses 
encouraged children to support other Blacks, by serving as role models, marrying within the race, and respecting elders.

In addition to racial pride, parents stressed the development of self-pride (6\%). "Be yourself, be proud of who you are." Five percent of the responses indicated that parents stress to their children that they are equal to Whites. "I teach them basically that even though people are separated by racial types...all people basically and fundamentally are the same- very little difference beyond the superficial."

Responses also indicate that parents teach moral values to their children as well (11\%). Parents teach spirituality and the importance of loving and trusting in God in order to overcome racism. Some parents indicate that God has made humans the same, and feel that race should be not be emphasized. In addition, parents teach the Golden rule of treating others fairly. Five percent of parents want their children to accept others, despite racial or gender differences. A small percentage of parents (2\%) teach their children to mistrust Whites, and encourage them to be suspicious of them.

The results from this question seem to support the research hypothesis that African-American parents teach their parents a variety of racial socialization messages. 
Table 5

Racial Socialization Messages

Frequency $\frac{\partial}{2}$ of Total Responses

Achievement

53

26

Importance of education

Must work harder than whites

Can achieve anything

Be the best you can be

strive to achieve

Racial Pride

Be proud to be Black

Black is beautiful

Being Black is positive

They are better than whites

Persons of great worth

Racism is not reflection of self

Racial pride in extreme is evil

Overcoming racism

Don't be held down by racism

Don't use racism as excuse

overcome obstacles

Handle racism diplomatically

Be prepared to cope

Stand up for rights

Be strong

Don't have chip on shoulder

Be aware of prejudice as occurs

Black heritage

Historical information

Knowledge of civil rights

knowledge of race

\section{Religion}

Children of God

Trust in God

God has blessed them

God has made us all different

Self-pride

Be proud of yourself

Feel good about yourself 
Table 5 (continued)

Reality of racism

11 5 Judged by skin color Will be denied opportunities will encounter difficulties Explanations of racism Can't get away with same as whites

Respect others Accept others for who they are

Be kind to others

Equal to Whites

Not inferior to whites

People are the same

You are American

Support other Blacks

Racism among Blacks

Marry other Blacks

Support other Blacks

Give back to the community

Respect elders

Mistrust Whites

Whites can't be trusted

Be aware of Whites' behaviors

Miscellaneous

Make up your own mind

Have good hygiene

Racism is evil

The results from these question are supported by the mean scores for individual questions on the racial and social awareness subscale. Parents indicated the importance of racial socialization to the extent of their agreement with specific questions. For the importance of racial socialization, questions included: Parents should teach their children what it means to be Black $(m=4.32)$; Parents 
have the responsibility of providing children with a sense of racial identity $(m=4.20)$; Parents shouid teach their children about racial problems in society $(m=4.19)$. These mean scores indicate that parents feel that racial

socialization is important, similarly to the $96 \%$ agreement of the importance of racial socialization found from the qualitative survey.

Specific messages of racial pride, reality of racism, and historical information were also supported through the racial and awareness subscale. For example, the questions "Children should grow up knowing that discrimination and racism will affect their lives" and "Children should be taught to be proud of their race" yielded mean scores of 4.29 and 4.78 respectively, indicating agreement. Similarly, parents disagreed with the following statements: Parents who teach children that Black is beautiful are wrong $(m=4.45)$; Black children who learn about Black history will learn to hate $(m=4.58)$; It is not important to teach Black children about their heritage $(m=4.33)$.

The third question was designed to elicit specific racial socialization messages taught to boys. Table 6 lists the specific messages taught to boys. Parents generated 180 responses to the question. Approximately one-third of the responses (33\%) indicated that parents teach their boys about negative stereotypes and images that are portrayed in the media. One parent described these negative messages in 
great detail:

Take for instance, the media. What is portrayed on the news is that most everything these young men do is negative, except for sports. So all they see is $t . v$. and sports stars in which $99 \%$ of them will never make it, but most believe they will. Advertisements in the media prey upon African-American boys. The music industry's so called "New Jack" music and negative rappers are probably the most influential messengers today on African-American boys. These rappers rap about violence, disrespecting women (Black), and having no respect for law and order. The subtle message is to get yours now, and don't worry about the future.

Besides the messages that Black men can only be successful through music and sports, other negative messages inciuded that Black men are perceived as lazy and as intellectually inferior to both whites and females. Parents convey that others do not expect Black men to achieve, and that others often have low expectations of them. Negative societal messages also included that Black boys are seen as angry, hostile, and aggressive, that they are drug users and abusers, that Black men are likely to end up in prison, and that they lack morals and are abusive to women.

The parents indicated that they teach their boys to overcome these negative stereotypes and media images (11\%). "I teach my son that he must be prepared to separate the facts from news images. I also teach him that he has a responsibility as, I do, to prove this image incorrect." Parents encourage their boys to stay away from drugs, and to stay out of trouble. "(N)ot to get into trouble, Black's don't get a 2nd chance." Boys are taught that they can do more than play sports and to serve as role models for 
others. Their sons are also taught to work hard, and that they may often have to work harder than whites in order to be perceived as successful. "Statistics snow you are often a target of racism, but as an individual you can/will overcome thru hard work and perseverance." "They must be better than White American boys just to be considered as good as."

Boys are also taught the reality of racism, and that they are at risk of being discriminated against $(8 \%)$. Parents seemed concerned that their boys respond to racism diplomatically and respectfully ( $8 \%)$. They encourage their boys to be polite if stopped by police, to not be perceived as aggressive or hostile, to have good manners, to speak properly, and to dress well.

If stopped by the police, be polite, and never reach for anything. Place your hands on the steering wheel at all times. If your license is in your pocket, let them reach for it. Keep your hands in full view.

They also caution their boys to be careful around whites, to watch for traps, and to not walk alone on the streets, especially in the deep South. One parent encourages her son to handle racism in a non-violent manner.

Responses suggested that parents emphasize the development of self-pride to boys ( 148 of responses). This included messages on the importance of self-reliance, taking responsibility for actions, setting goals, and striving to achieve. "(H)old your head up and take pride in who you 
are. Be a man, get your education, take responsibility for your actions..." "First, keep your self-respect." Six percent of the responses stressed the importance of achievement and education. "Get a good education." "Don't stop short of getting your college degree." Surprisingly, only $2 \%$ of the responses directly indicated teaching boys racial pride or historical information.

Parents communicate the importance of morals and values to their sons. Nine percent of the responses emphasized the importance of family values. Parents want their sons to be respectful of Black women, and to only marry Black women. "Love and respect your Nubian princesses." They are encouraged to marry someone with compatible interests, and to communicate openly. Parents stress the importance of fatherhood and responsibility. "Be a positive provider for your family." Four percent emphasize the importance of spirituality and religious beliefs. Finally, parents ask their children to respect others, and to judge people by their character (3\%). 
Table 6

Racial Socialization Messages for Boys

Frequency $\frac{2}{2}$ of Total Responses

Negative stereotypes

60

33

Cannot achieve

27

Only succeed at sports, music

Cannot achieve

Lazy and stupid

Inferior to Whites

Inferior to women

Low expectations of them

Troublemakers

Drug dealers/ criminals

End up in jail

Anary image

4

Macho and tough

Angry young men

They are feared

Disrespect others

Have illegitimate children

Don't support children

Abusive towards spouses

Use women

Miscellaneous

Low self-esteem

Lack morals

They are not important

Some jobs not for them

Self-pride

Self-pride

Responsible for own actions

Be strong

Be best can be

Be self-reliant

Self-esteem

Set goals

Self-awareness 
Table 6 (continued)

Overcoming negative images

Don't accept stereotypes

Erequency of Total Responses

Be role models

Don't use drugs

Stay out of trouble

Value of Family

Respect Black women

Marry Black women

Be good fathers

Stay away from white women

Communicate with mate

Value of the family

Be the breadwinner

Marry person with compatible interests

Reality of racism

At risk of racism

Harder to succeed than women

Handling racism

Be cautious around whites

Be polite to police

Dress well

Good manners

Don't be aggressive

Handle racism nonviolently

Speak proper English

Be prepared to give your life

Achievement

Importance of education

Importance of hard work

Moral values

Have good morals

Respect others

Judge people by character

Racial pride

Historical information

Racial pride

Miscellaneous

Value of money

Choose friends carefully

Boys don't cry 
The fourth and final question was to determine the specific messages taught to girls. Table 7 lists the specific messages that parents indicated that they teach to girls. There were 159 responses to this question. The majority of responses indicated negative stereotypes and images given to girls.

...African-American girls of low socioeconomic backgrounds to receive a much greater dose of negative messages. Besides seeing teenage pregnancy, drug dealing, lack of a father figure, the black boys will be disrespecting them from the subtle messages they have been receiving. Many African-American girls will attempt to use sex for love and attention.... (T)he media... lead us to believe that most of the people on welfare are Black women with a large number of babies.

Parents indicated that girls are perceived as lazy, drug abusers, on welfare, at risk for illegitimate children, and used only a sex objects. They are told that the only jobs readily offered to them are as servants as they are inferior to whites. Finally, parents discussed the issue of physical attractiveness based on white standards.

At 3 years old she's read stories about goldie locks and snow white and how beautiful that they are. So she is developing a concept of beauty. She looks in the mirror and see that she is not white as snow nor does she barely have any locks on her head at all in a lot of cases, so she's disappointed.

Girls are given specific messages on the development of self-pride (13\%). They are encouraged to believe in themselves and their beliefs, and to be their own person. "To carry yourself with pride and dignity." "Be proud, always of yourself-keep your self-respect." "Most of all believe in yourself." Parents indicated that they teach 
girls racial pride as well (11\%). They are taugnt that they are beautiful and to not judge their physical attractiveness against white standards. "They are beautiful but differently beautiful because they are black." "Black hair is different from white hair and this must be accepted." They are also taught about their African-American heritage, and encouraged to participate in cultural activities. Girls are encouraged to take pride as their role as the mothers of mankind and of their race. "The fact that female are the "mothers" of our nation. As such, there is a special call for their nurturing our upcoming generations."

Girls are taught the importance of education and achievement (13\%). "You can succeed but an education is necessary." "Get a quality education." Girls are encouraged to work hard and to be the best they can be, although they are told they will have to work harder than others to be successful. "Work hard to achieve your goals you set for yourself." "...that black women in particular have to work harder, be more self-sufficient, and independent." "You can be whatever you want to be, but must put forth more effort than others."

Parents communicate not only the reality of racism, but the pressure of sexism that African-American girls will face (68). "African American women have conquered many a challenge that is even rougher not only being black but because they are women." "A special burden is put on Black 
women. They must be on guard against white men and women and that they must also understand that they even threaten some Black men." Girls are also told that they are often a threat to others in the work place, although it will be easier for them to obtain jobs than African-American men. However, only $5 \%$ of the responses include suggestions for coping with racism. They are encouraged to stay off of drugs, and to not accept stereotypes. "Try not to get into trouble and please stay off drugs."

Girls are taught messages of moral values by their parents $(13 \%)$. They are taught to love and trust God. Girls need to behave as ladies, not wear suggestive clothing, and to serve as role models. "Be wonderful, lovely women. Don't wear suggestive clothing." "Always be and act, dress like a lady." Girls are also given explicit messages to not engage in premarital sex due to the risk of having illegitimate children (3\%).

Parents give girls specific messages about their relationships with African-American men ( $6 \%$ of responses). They are encouraged to be supportive of men, but to demand respect from them. "Black women need to support and uplift the black male." "(T)aught to make the Black males respect them." Girls are told that they should be independent and that they can survive without men. "Make sure you don't start life expecting to be dependent on no man other than God. Make sure at all times you can provide and make a 
living for yourself." Girls are also encouraged to protect and support families, and to be nurturant. "Emphasis should be put on family and keeping it together." 
Table 7

Racial Socialization Messages for Girls

Frequency $\stackrel{2}{2}$ of Total Responses

Negative stereotypes

40

25

Negative images

8

On welfare

Drug abusers

Lazy

Hostile

Must look white to be pretty 8

Illeditimate children

Have illegitimate children

Are teenage mothers

Don't take care of children

Sex objects

Bodies only for sex

Sexually active

Inferior to whites

Not as smart as whites

Not as good as whites

Can't make it in job market

Roles

Work as servants

Can only cook and clean

Will receive negative messages 2

Miscellaneous

Have low self-esteem

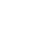

Black men are worthless

Self-pride

Self-pride

Be strong in beliefs

Believe in self

Be your own person

Do what will make you happy

Use your mind

Be responsible for yourself 
Table 7 (continued)

Achievement

Importance of education

Frequency of Total Responses

Do your best

Can do anything

Work hard to achieve

set goals

Racial pride

17

11

Racial pride

Black is beautiful

History

Mother of our nation

Mother of mankind

Participate in multicultural activities

Moral values

Trust God

Good morals

Don't wear suggestive clothing

Be a role model

Judge others by their character

No premarital sex

Value of family

10

6

Support Black men

Support families

Marry Blacks

Reality of racism

Face racism and sexism

Threat to Black and White men

singled out by white women

Be prepared for the worst

Have advantages over Black men

Coping mechanism

Don't accept stereotypes

Play game well

Stay off drugs

Don't be abused

How to handle herself

watch your back 
Table 7 (continued)

Relationship with men

Don't depend on men

Demand respect from men

Don' $t$ believe macho image

Black men may choose white women

Miscellaneous

3

2

Be in the background

Not threatening to whites

Derision among Black females

It was hypothesized that racial socialization messages would differ according to gender. A chi-square analysis was conducted to determine if the frequencies of messages determined through open coding differed significantly according to gender. The results indicated that boys do tend to receive different racial socialization messages than girls $\left(v^{2}=13.633, p<.05\right)$. Boys received more messages on negative stereotypes or societal messages, and received a greater percentage of coping strategies to deal with racism. Girls, however, were given more messages on the importance of achievement. Girls also received messages on racial pride than boys, although they were given an equal percentage of messages on self-pride. Finally, girls received messages on premarital sex, whereas boys did not. The findings support the research hypothesis that boys would receive messages on overcoming racial barriers and oppression, as well as the hypothesis that girls would receive messages on racial pride and sexuality. 


\section{CHAPTER V \\ DISCUSSION}

The results of the study generally support the research hypotheses. Parents seem to feel that racial socialization of children is important and often necessary to help children deal with racism and oppression. They give children a variety of messages about racial issues, and the types of messages given seem to differ according to the gender of the children. This chapter will discuss the research findings and implications from the current study. Limitations of the study, including difficulty with research methodology will be discussed. Finally, suggestions for future research will be provided.

General Research Findings

There were no hypotheses on the relationship between demographic variables and racial socialization attitudes. Gender, however, was found to relate significantly with racial socialization attitudes, as women were found to have stronger socialization attitudes than men. African-American men often experience more racism and oppression than African-American women. African-American men may respond to racial experiences with anger and resentment, shame, and feelings of impotence (Herbert, 1990). These feelings may 
lead them to spend less time discussing racial issues with their children. Women traditionally have served as nurturers and caregivers within the family, and may more often perform the task of socialization, including racial socialization (Greene, 1992b).

Racial identity attitudes seem to impact racial socialization attitudes. It was hypothesized that preencounter attitudes would have a significant negative relationship with racial socialization attitudes as parents would hold low salience to race and racial issues. This finding was not supported in the regression analysis, but preencounter scores were significantly negatively correlated with racial socialization attitudes. Encounter attitudes were not expected to relate significantly to racial socialization attitudes as individuals with encounter attitudes tend to be confused and uncertain of their racial identity. This confusion could lead to uncertainty around the importance of racial socialization. In the current study, encounter attitudes did not relate significantly to racial socialization attitudes, lending some support to the research hypothesis. Immersions scores were not found to relate significantly with racial socialization attitudes. This finding may be due to the low reliability and low correlation between immersion and racial socialization attitudes. Parham and Helms (1985a) suggest that immersion attitudes correlate negatively with self-esteem as immersion 
attitudes, especially militant reactions, are an attempt to overcompensate for negative feelings experienced in the past. Individuals with immersion attitudes often feel guilt, shame, and insecurity (Parham \& Helms, 1985a). In a similar manner, parents with immersion attitudes may feel guilty about their prior attitudes and may find it difficult to socialize their children as they are still in the process of developing their own racial identity, and may not have internalized changes. They may also rely on implicit socialization messages, such as participation in civil rights activities, to influence their children. Because of the anger held towards whites, parents with immersion attitudes may simply denigrate whites without teaching or giving their children positive messages on being AfricanAmerican .

Although it was hypothesized that internalization attitudes would not relate significantly to racial socialization attitudes, internalization attitudes were found to have a positive significant relationship with racial socialization attitudes. This suggests individuals with strong internalization attitudes feel that it is important to racially socialize their children. Parham and Helms (1985a) found that internalization attitudes had a significant positive relationship with self-esteem as individuals have explored their identity and are comfortable with their values. Similarly, parents with internalization 
attitudes may feel comfortable with their identity and consequently feel that it is important to socialize their children. They feel less anger towards whites than individuals with immersion attitudes, and may give messages to children on racial pride, as well as the development of self-pride, and respect for other cultures and values.

The study found that the overwhelming majority (96\%) of parents in the sample feel that racial socialization is important, due to the reality of racism and oppression, and to the importance of helping their cnildren to cope effectively with racism. The parents indicated that they are the ones who must socialize their children, as peers and teachers may give children misinformation, and Black history is often not taught within the school system. Parents also hope that their children will have an impact on the future, and will help others to change their racial attitudes. The results from the qualitative results were corroborated by the quantitative measure. The results from this study support findings from previous research that examined the importance of racial socialization. When asked directly, parents indicate that they do racially socialize their children (Thornton, et al., 1990: Peter, 1985). Studies that ask individuals retrospectively about racial socialization messages often suggest that parents do not socialize their children (Sanders Thompson, 1994; Parham \& Williams, 1993: Bowman \& Howard, 1985). The results from 
the current study indicate the importance of studying parents directly on their attitudes and that research findings can be an artifact of design.

Parents were able to list a plethora of specific racial socialization messages given to their children. Specific messages included the importance of achievement, the reality of the presence and nature of racism, specific coping strategies, African heritage, religion and spirituality, racial pride, self-pride, noral values, and eqalitarian messages. Models for categories of racial socialization messages have been postulated in the literature. Boykin and Toms (1985) classified families according to three categories, mainstream, minority socializing, and Black cultural families. Mainstream parents tend to give messages on Eurocentric values, minority socializing parents passively accept racism and oppression, while Black cultural families teach their children about African heritage, and Afrocentric values. Sanders Thompson (1994) suggests that racial socialization messages fall into four categories, racial identity, self-development, racial barriers, and egalitarianism. Racial identity messages focus on racial pride, self-development messages focus on achievement, racial barriers messages focus on overcoming racism and oppression, and egalitarian messages focus on equality and universal characteristics.

The results from the current study support these 
categories. Families give messages on the importance of self-pride, achievement, and education, messages that are often given by caucasian parents and conform with Eurocentric values. These messages are similar to the mainstream families, and messages on self-development. Parents within the current study responded with messages on racial pride, importance of religion and spirituality, and African heritage, which is similar to the Black cultural families and messages on racial identity. Parents also teach their children that they are equal to whites and to respect others, similarly to egalitarian messages. Parents in the study also indicated racial barriers messages, including the reality of racism, and coping strategies. Messages similar to minority families were not found in study as minority families tend to passively accept racism (Boykin \& Toms, 1985), and the parents in this study felt very strongly that racial socialization is important.

Previous research suggested that boys and girls receive different racial socialization messages. Boys tend to receive messages on the racial barriers and egalitarianism, while girls tend to receive messages on racial pride (Bowman \& Howard, 1985). Parents in the current study reported that they give both boys and girls messages on racial pride, self-pride, importance of achievement, negative societal messages, overcoming racism, moral values, and the importance of the family. Boys, however, received more 
messages on overcoming racism, although girls are encouraged more to pursue a good education. Although boys and girls receive an equal percentage of messages on self-pride, girls tended to receive more messages on racial pride. Both of these findings support the previous research findings. Girls, however, received messages on premarital sex, and relationships with men. Girls were encouraged to not engage in premarital sex, and to not be used by both Black and white men within relationships, whereas boys did not receive these types of messages. Additional messages may occur as parents are aware that their female children may face difficulties within this country due to both their race and their gender. Greene (1992b) discusses the challenges that African-American women face in socializing their female children due to the sexism they would experience. She states that African-American females often internalize racism, especially around physical attributes and standards for beauty. Many of the parents in the current study also discussed the importance of teaching their female children the importance of accepting their physical beauty. In addition, due to the large number of teen mothers within the African-American community, parents may be concerned with issues of their daughters sexuality. Some of the parents indicated that they felt that their daughters would be solely responsible for a teenage pregnancy. In addition, parents encouraged their girls to maintain their 
independence, including financial independence, in case they were abandoned by their partners.

Several implications can be drawn from the results. As parents with strong internalization attitudes were more likely to feel that racial socialization of children is important, it may be important to encourage parents to develop racial pride and internalize their attitudes. Hopson and Hopson (1990) encourage parents to openly communicate with their children. Parents should openly discuss racial issues, provide positive modeling, and reinforcement of Blackness. Efforts through counseling, parenting groups, and through community activities should be made to encourage and enhance the racial identity development of parents.

Although no attempt was made in the study to assess children's racial identity attitudes, it may be implied that parental socialization is in important factor in the development of racial identity attitudes in children. Ford, Harris, and Scheurger (1993) emphasized the importance of parents in the socialization process of African-American children who must develop bicultural skills. When adolescents appear for therapy because they are facing racism and oppression, or are experiencing difficulty in forming their racial identity, they stress that parents must be included in the therapy and encouraged to socialize their children (Ford, Harris, \& Schuerger, 1993). Family 
therapists should assess the racial identity attitudes of each family member, as they may often differ (Gushue, 1993), and encourage open communication of racial issues. Children are often afraid to discuss racial issues with their parents for fear of disappointing them (Hopson \& Hopson, 1990). Family therapists, therefore, can play a critical role in enhancing open communication, and encouraging growth and change in racial identity development in all family members. Limitations of the study

This study may enhance the rields of counseling psychology, child development, and family therapy as it provides a better understanding of parental socialization of African-American children. However, there are several limitations to the study. First, the study is limited by the self-selection of subjects. Helms (1989) stated that self-selection in racial identity studies will result in the selection of subjects in higher racial stages as they are more interested in racial issues. The mean scores for internalization attitudes within the current study were higher than the means for the other subscales with the racial identity measure. Parents with a predominance higher racial identity attitudes may have elected to participate in this study due to their beliefs of the importance of racial issues. Therefore, the study may reflect the parental attitudes and socialization beliefs of parents with stronger pro-Black attitudes and values. 
One difficulty with the self-report measure is that parents may only list responses that they can easily recall. or they may also have listed messages that they would like to give their children. Observations of parent-child interaction may very well indicate that the parents behave in ways that differ from their self-reports.

Another concern with self-selection and the self-report measures is that parents may have given answers that they viewed as socially acceptable for racially focused research. The parents were invited to participate in a racial identity workshop with the researcher. Although the workshop was conducted after surveys were administered and collected, the parents may have answered items in a way that would indicate strong pro-Black values despite their personal beliefs which at times may differ. The third limitation concerns the geographical location from which the subjects were selected. Parham \& Williams (1993) researched adults nationwide and suggested that racial attitudes vary across geographic regions. As the sample for this study was drawn from a Southern state, the generalizability of the study may be restricted. The data, however, may reflect the viewpoint of many African-American parents who encounter racism and oppression or are aware of or fear their children facing similar experiences.

The major limitation with the study lies with the measure to assess racial identity attitudes. The 
reliability coefficients in the study were lower than those previously found. The racial identity scale was normed with college students ages 18-24 years, whereas the sample in this study were older, with more college and graduate school experience. The results from this study may indicate that the RIAS is best suited for a college age sample. Helms (1990) questions whether the instrument is suitable for noncollege populations. In addition, the intercorrelation coefficients found in the current study differed substantially from those obtained in previous studies. Preencounter was found to be significantly correlated with immersion and internalization attitudes, and immersion attitudes were also found to relate significantly with internalization attitudes. According to the cross (1991) model, the stages and subsequent attitudes should be independent and should not correlate. This again may suggest the unsuitability of the instrument for non-college populations. This suggests the unsuitability of the instrument and that it does not reflect the theory.

In addition to the low reliability of the scale, the racial identity attitudes did not correlate significantly with the racial and social awareness subscale, with the exception of internalization attitudes. The low reliability and correlation with racial socialization attitudes may account for the surprising finding that immersion attitudes had a negative relationship to racial socialization 
attitudes. It was hypothesized that parents with strong pro-Black attitudes as is usually found in immersion attitudes would feel that racial socialization is important. However, immersion attitudes may differ from Afrocentric values and attitudes. As the RIAS had low reliability, perhaps a measure of Afrocentrism, such as the African SelfConsciousness Scale (Baldwin \& Bell, 1985) would have yielded more significant results. For instance, Branch and Newcombe (1986) found that a measure of Afrocentrism, the Black Ethnocentrism Scaie (Chang \& Ritter, 1976), correlated positively and significantly with racial socialization attitudes.

The racial socialization measure had moderate reliability. However, the insignificant findings in the study may have been found as the racial and social awareness subscale was the only dependent variable tested with the racial identity attitudes in the study. The research may have been enhanced by including an additional empirical measure of racial socialization.

Nonsignificant findings may also have been found as the participants had less strong preencounter, encounter, and immersion attitudes. The participants in the study reported strong internalization attitudes, with little variation within the mean scores for attitudes. The range restriction of the scores may also contribute to insignificant findings. The limitations due to the difficulty with the racial 
identity attitude measure, however, were compensated for through the use of qualitative measures. Due to the exploratory nature, both qualitative and quantitative measures were utilized. Using a quantitative measure that simply places individuals in stages loses information about particular behaviors within stages at different ages (Phinney, 1988; Helms, 1989; Ramsey, 1987). Schofield and Anderson (1987) stated that qualitative measures provide an understanding of perceptions and feelings, the manner of relating and behavior patterns for groups, and is therefore well-suited for ethnic identity studies. Craig-Bay and Adams (1986) discussed the limitations of self-report measures and interview schedules, more qualitative measures, in identity research. Participants may be more inclined to give socially acceptable answers to self-report checklist items. Interview schedules and open-ended questions usually have low validity and it is difficult to achieve interrater reliability (Craig-Bay \& Adams, 1986). This study benefitted from the combination of measures which provides triangulation on data to improve both the reliability and validity of the findings of the research. Suggestions for Future Research

Previous research that examined racial socialization retrospectively found that adults reported that they were often not socialized to racial issues by their parents. This study indicates that parents believe in the importance 
of racial socialization, and offer a variety of messages to their children, and support previous studies that examine parents directly. This suggests that future studies that focus on racial socialization should measure parents directly, as retrospective studies may not directly measure racial socialization.

This study made no attempts to assess racial identity attitudes in children. There were also no efforts to determine the impact of parental socialization beliefs on the identity development of children. Parents may give children mixed messages around racial issues (Boykin \& Toms, 1985). Future studies should attempt to correlate parental beliefs and attitudes with children's racial identity attitudes.

Due to self-selection biases, this study had a majority of parents with stronger internalization attitudes who may believe in the importance of racial socialization, future studies should attempt to include parents with other attitudes. Thornton, Chatters, Taylor, and Allen (1990) surveyed parents on a variety of issues. Parents who have less strong Afrocentric values may be more likely to participate in a study if the primary focus does not appear to be on racial identity. Due to the negative implications of negative racial identity, it is important to assess socialization attitudes of all parents, not just parents with strong internalization attitudes. 
Families of differing socioeconomic backgrounds experience racism and oppression in different manners, suggesting that differing socialization practices may be necessary (Boyd-Franklin, 1989; Smith, 1989). Pressures may also differ according to the environment in which families live, either predominantly African-American, predominantly Caucasian, or mixed. Children may receive different messages at school and within the environment. The sample in this study were primarily middle- and upper-class individuals, and the results may not be generalizable to African-American lower class families. Future studies should attempt to include participants from a variety of backgrounds.

Messages seem to differ according to the gender of the child. Racial identity models have been criticized as they do not address other dimensions of the individual (Smith, 1989). For example, can race and gender be considered as separate entities within the identity of an individual? Reynolds and Pope (1991) suggest a multidimensional model that incorporates multiple aspects of identity. Future research on socialization should attempt to account for multiple variables, including race/ethnicity, gender, and sexual orientation.

Finally, research needs to examine implications for family therapy and community interventions. Can parent's attitudes be changed through therapy, parenting groups, or 
other interventions? How would these changes effect children's racial identity development? Future studies should focus on the outcome of interventions, and determine implications for changes within racial identity.

In summary, this study provides evidence that racial identity attitudes influence racial socialization attitudes in African-American parents, indicating that parents with strong internalization attitudes have strong racial socialization attitudes. The majority of parents when asked directly indicated the importance of racial socialization, and provided racial socialization messages for both boys and girls. These messages can be used in individual and family therapy, as parents who indicate that they do not racially socialize their children should be encouraged to socialize them. especially if their children are likely to encounter negative racial experiences. The study lends support to the methodology that examines parent on their attitudes directly, although future attempts should be made to determine the impact of parental messages on children's racial identity. 
APPENDIX A 


\section{Parental Attitude Scale}

This scale was designed to measure opinions on child-rearing. Please circle the response that corresponds to your opinion for each of the statements.

$S A=$ Strongly $A=$ Agree $\quad U N=$ Undec ided $D=D$ isagree $S D=$ Strongly agree

disagree

1. Children should be we 11 mannered and respectful to adults at all times.

2. Dirty children are happy children.

SA A UN D SD

3. Children should grow up knowing that discrimination and racism will affect their lives.

4. Parents should show their children love and affection.

5. Hollering at children is a good way of making them mind.

6. It is alright for children to misbehave in front of company.

7. People who teach the ir children that "Black is Beaut ifu l" are wrong.

8. Parents who let their children do what they want to do are not good parents.

9. Children below the age of ten (10) cannot be expected to help out in the house.

10. Children need to rely on themselves to succeed in life.

11. Black children who learn about black history will learn to hate.

12. Children should be taught to be proud of their race.

13. Children should look to their parents for guidance about racial matters.

14. Parents should teach their children what it means to be Black.

15. All children should learn to have faith in God.

16. Parents should teach children not to talk back to the ir elders.

17. Parents should insist on their children going to church.

18. Parents should be respected.

SA A UN D SD

SA A UN D SD

SA A UN D SD

SA A UN D SD

SA A UN D SD

SA A UN D SD

SA A UN D SD

SA A UN D SD

SA A UN D SD

SA A UN D SD

SA A UN D SD

SA A UN D SD

SA A UN D SD

SA A UN D SD

SA A UN D SD

SA A UN D SD

SA A UN D SD

19. Children should be allowed to disagree with the ir parents.

SA A UN D SD 
$S A=\begin{gathered}\text { Strongly } \\ \text { agree }\end{gathered} \quad A=$ Agree $\quad U N=$ Undecided $\quad D=D$ isagree

20. Children should be encouraged to get to know their relatives.

21. Children should be allowed to do what they want to do as long as it does not hurt anyone else.

22. Parents should not require the ir children to attend church.

23. A child who misbehaves should be punished.

24. Parents who do not tell their children that America is the "Land of the Free" only for white folks are doing their children an injustice.

25. People should keep in close touch with their family.

26. Children raised to serve the Lord grow up to be fine adults.

27. Parents should tell their children that white people can be trusted.

28. Children should be taught to respect their elder kin.

29. A parent's religion provides the on ly framework in which children should be reared.

30. Firm discipline is necessary to keep children under control.

31. Parents have the responsibility of providing children with a sense of racial identity.

32. Black children should be taught by their parents that they are an African people.

33. Parents should teach their children to heip their relatives if they are in need of assistance.

34. Children should learn early to do things for themselves.

35. Children should learn how to dress in style.

36. Parents ought to make sure their children believe in the same religion they believe in.

37. Children should be taught that cleanliness is next to Godliness.

38. It is not acceptable for a child to live with relatives other than his own.

39. Learning to clean a house is something every parent should teach a child.
$S D=$ Strongly

SA A UN D SD

SA A UN D SD

SA A UN D SD

SA A UN D SD

SA A UN D SD

SA A UN D SD

SA A UN D SD

SA A UN D SD

SA A UN D SD

SA A UN D SD

SA A UN D SD

SA A UN D SD

SA A UN D SD

SA A UN D SD

SA A UN D SD

SA A UN D SD

SA A UN D SD

SA A UN D SD

SA A UN D SD

SA A UN D SD 
$S A=$ Strongly $A=$ Agree $\quad U N=$ Undecided agree

$D=D$ isagree

$\mathrm{SD}=$ Strongly

disagree

40. Parents should never force a child to do something he/she doesn't want to do.

SA A UN D SD

41. Children should not be trained to do things for themselves at an early age.

42. Children should be raised in the church.

43. Parents who are permissive with their children are not doing a good job raising them.

44. Parents should make sure their children learn how to keep themselves clean.

45. Family reunions should be held at least once a year.

46. Parents whose children stay dirty should not be allowed to keep them.

47. Children should not have the responsibility for taking care of younger brothers and sisters.

48. Religion is not important in the upbringing of children.

49. Children should be able to help with household chores (such as cooking, cleaning, and shopping) by the time they are ten (10) years old.

50. Someone other than a parent should teach children about racial awareness.

51. Parents should choose for their children what occupation they should have in the future.

52. Spanking a child is the best way to make him/her SA A UN D SD mind you.

53. Teaching Black children Black pride is harmful to them.

54. Parents should encourage children to try new things without their help.

SA A UN D SD

SA A UN D SD

SA A UN D SD

SA A UN D SD

SA A UN D SD

SA A UN D SD

SA A UN D SD

SA A UN D SD

SA A UN D SD

SA A UN D SD

SA A UN D SO

SA A UN D SD

SA A UN D SD

55. Parents who stress cleanliness to their children are too "fussy".

SA A UN D SD

SA A UN D SD

56. Parents should teach their children about racial problems in society.

57. Black children who are sheltered from racial problems are likely to find it harder to cope with society when they leave home.

58. It is not important to teach Black children about SA $A$ UN $D$ SD the ir heritage.

SA A UN D SD 

$S A=\begin{gathered}\text { Strongly } \\ \text { agree }\end{gathered} \quad A=A g r e e \quad U N=$ Undecided $\quad D=D$ isagree $\quad S D=\begin{gathered}\text { Strongly } \\ \text { disagree }\end{gathered}$

59. Parents should encourage children to make their own decisions.

60. Children are entitled to decide for themselves what religion to follow.

SA A UN D SD

SA A UN D SD

SA A UN D SD

61. Young people should be able to leave home to start life on the ir own by the time they are 18 years old.

62. Families who regularly attend church have fewer problems with their children.

63. Parents should make sure that religion is part of every child's life.

64. The stricter the parent the better the child will become.

65. Black children should learn early not to trust white people.

66. Children should be carefully supervised in what they are allowed to do.

67. Marrying outside of one's race should be discouraged.

68. Children should be taught religious principles.

69. Allowing children to have their way will help them to grow up to be independent.

70. Parents know what's best for the ir children.

71. It is acceptable for a person who is successful to refuse to help his/her family and relatives.

72. Parents should teach the ir children to be loyal to the family.

73. Children who can take on many different family responsibilities will be an asset to the family.

74. A clean home helps children to learn to be clean.

75. Children should be allowed to express anger at the ir parents.

76. Children should take care of their parents in their old age.

SA A UN D SD

SA A UN D SD

SA A UN D SD

SA A UN D SD

SA A UN D SD

SA A UN D SD

SA A UN D SD

SA A UN D SD

SA A UN D SD

SA A UN D SD

SA A UN D SD

SA A UN D SD

SA A UN D SD

SA A UN D SD

SA A UN D SD 
APPENDIX B 
SOCIAL ATTITUDE SCALE

This questionnaire is designed to measure people's social and political attitudes. Please circle the appropriate number corresponding to your opinion of each statement as follows:

\begin{tabular}{lcccc}
\hline Ttrongly & 2 & 3 & 4 & 5 \\
Disagree & Disagree & Uncertain & Agree & $\begin{array}{c}\text { Strongly } \\
\text { Agree }\end{array}$ \\
\hline
\end{tabular}

1. I believe that being Black is a positive experience. $\begin{array}{lllll}1 & 2 & 3 & 4 & 5\end{array}$

2. I know through experience what being Black in America 122345 means.

3. I feel unable to involve myself in White experiences, $1 \begin{array}{lllll}1 & 2 & 3 & 4 & 5\end{array}$ and am increasing my involvement in Black experiences.

4. I believe that large numbers of Blacks are untrustworthy.

5. I fee 1 an overwhelming attachment to Black people. $\quad \begin{array}{lllll}1 & 2 & 3 & 4 & 5\end{array}$

6. I involve myself in causes that will help all $\quad 1 \quad 2 \quad 3 \quad 4 \quad 5$ oppressed people.

7. I feel comfortable wherever I am.

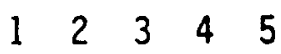

8. I believe that white people look and express themselves better than Blacks.

9. I feel very uncomfortable around Black people. $\quad 1 \quad 2 \quad 3 \quad 4 \quad 5$

10. I feel good about being Black, but do not limit $\quad \begin{array}{lllll}1 & 2 & 3 & 4 & 5\end{array}$ myself to Black activities.

11. I often find myself referring to white people as $\quad \begin{array}{lllll}1 & 2 & 3 & 4 & 5\end{array}$ honkies, devils, pigs, etc.

12. I believe that to be Black is not necessarily good. $\begin{array}{lllll}1 & 2 & 3 & 4 & 5\end{array}$

13. I believe that certain aspects of the Black experience $1 \begin{array}{lllll}1 & 2 & 4 & 5\end{array}$ apply to me, and others do not.

14. I frequently confront the system and "the man".

$\begin{array}{lllll}1 & 2 & 3 & 4 & 5\end{array}$

15. I constantly involve myself in Black political and social activities (art shows, political meetings, Black theatre, etc.). 
Strongly

2

3

4

5

Disagree

Disagree

Uncerta in

Agree

Strongly

Agree

16. I involve myse if in social action and political groups even though there are no other Blacks involved.

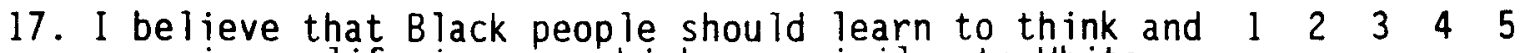
experience life in ways which are similar to white people.

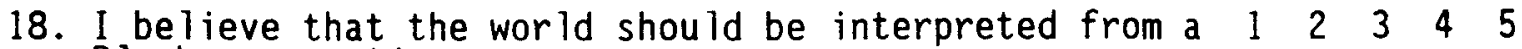
B lack perspective.

19. I have changed my style of life to fit my beliefs $\quad \begin{array}{lllll}1 & 2 & 3 & 4 & 5\end{array}$ about Black people.

20. I feel excitement and joy in Black surroundings. $\quad \begin{array}{lllll}2 & 3 & 4 & 5\end{array}$

21. I believe that Black people came from a strange, dark, $\begin{array}{llllll}2 & 3 & 4 & 5\end{array}$ and uncivilized place.

22. People, regardless of the ir race, have strengths and $1 \begin{array}{llll}2 & 3 & 4 & 5\end{array}$ limitations.

23. I find myself reading a lot of Black literature and $\begin{array}{lllll}1 & 2 & 3 & 4 & 5\end{array}$ thinking about being Black.

24. I feel guilty and/or anxious about some of the things $\begin{array}{lllll}1 & 2 & 3 & 4 & 5\end{array}$ I believe about Black people.

25. I believe that a Black person's most effective weapon $1 \begin{array}{lllll}2 & 3 & 4 & 5\end{array}$ for solving problems is to become a part of the White person's world.

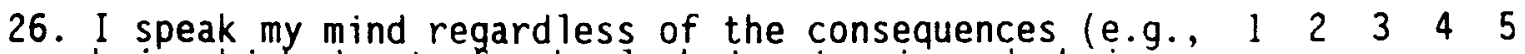
being kicked out of school, being imprisoned, being exposed to danger).

27. I believe that everything Black is good, and consequently, I limit myse If to Black activities.

28. I am determined to find my Black identity.

29. I bel jeve that White people are intellectually superior to Blacks.

30. I believe that because I am Black, I have many strengths. 
APPENDIX C 
Parental Survey

1. Gender:

Male

Female

2. Age:

3. Marital Status: Single Married Divorced/Widowed

4. Number of Children:

5. Ages and Gender of Children (i.e., 13 yr. old girl):

6. What is your occupation?

7. What is your family's income?
— $\$ 10,000$ or less $\$ 30,000$ to $\$ 40,000$
- $\$ 11,000$ to $\$ 20,000$ $\$ 40,000$ to $\$ 50,000$ $\$ 21,000$ to $\$ 30,000$ $\$ 51,000$ or more

8. What is the last year/grade of school completed?

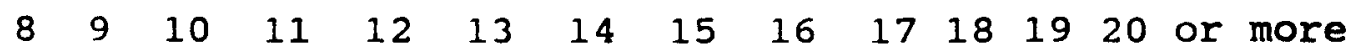
9. Do you feel that it is important to teach your child(ren) about racial issues? If so, why? If not, why not? (Use the back of the page if necessary). 
10. If you teach your children about racial issues, what type of messages do you tell your children about being Black/African-American?

11. What are specific racial messages taught to AfricanAmerican boys? 
12. What are specific racial messages taught to AfricanAmerican girls? 
102

APPENDIX D 
1212 S. Forums Ct., $1 \mathrm{~A}$ Wheeling, IL 60090

January 15, 1994

Dear Parents of First Baptist Church:

I am a doctoral student in Counseling Psychology at Loyola University Chicago. I am conducting a study on social attitudes and childrearing as my dissertation. I would like to take this opportunity to invite you to participate in the study.

The study involves the one time completion of three surveys. Each survey asks for your opinions and there are no right or wrong answers. Participation in the study is voluntary, and the return of the surveys indicates your consent to participate. The completion of the surveys should take thirty to forty minutes. After completing the surveys, you may return them to the Church library or Church office, leave them with Mrs. Bernice Jones, or you may mail them to me in the enclosed envelope.

All results will be collected anonymously. Code numbers that appear on the survey only serve to coordinate surveys from the same family, but are not connected to your name. To assure anonymity, please do not put your name on any survey .

If you have any questions about participating in the survey or would like to make comments, you may reach me during the day at (708) 356-3322, and at home at (708) 808-8132. You may also reach Dr. Speight, the dissertation chair, at (312) 915-6034.

Thank you for your support and participation. sincerely,

Anita Jones Thomas, MA 


\section{REFERENCES}

Aboud, F. E. (1987). The development of ethnic self-identification and attitudes. In J. S. Phinney \& M. J. Rotheram, (Eds.), Children's ethnic socialization: Pluralism and development, (32-55). Newbury Park: Sage. Akbar, N. (1989). Nigrescence and identity: Some

limitations. The Counseling Psychologist, 17, 258-263. Alejandro-Wright, M. N. (1985). The child's conception of racial classification: A socio-cognitive developmental model. In M. B. Spencer, G. K. Brookins, \& W. R. Allen (Eds.), Beginnings: The social and affective development of Black children. Hillsdale: Lawrence Erlbaum Associates.

Aries, E. \&, Moorehead, K. (1989). The importance of ethnicity in the development of identity of Black adolescents. Psychological Reports, 65, 75-82.

Atkinson, D. R., Morten, G. , \& Sue, D. W. (1989).

Counseling American minorities. Dubuque: Wm. C. Brown. Baldwin, J. A., \& Bell, Y. R., (1985). The African

Self-Consciousness Scale: An Africentric personality questionnaire. Western Journal of Black Studies, $9(2)$, $61-68$.

Banks, J. A. (1984). Black youths in predominantly white 
suburbs: An exploratory study of their attitudes and self-concepts. Journal of Negro Education, 53(1), 3-17. Barnes, E. J. (1991). The Black community as the source of positive self-concept for Black children: A theoretical perspective. In R. Jones, (Ed.), Black psychology, (667-692). Berkeley: Cobb and Henry. Bowman, P. J., \& Howard, C. (1985). Race-related socialization, motivation, and academic achievement: $A$ study of Black youths in three-generation families. Journal of the American Academy of Child Psychiatry, $\underline{24}(2), 131-141$.

Boyd-Franklin, N. (1989). Black families in therapy: $A$ multisystems approach. New York: Guilford Press. Boykin, A. W., \& Toms, F. D. (1985). Black child socialization: A conceptual framework. In H. P. McAdoo, \& J. L. McAdoo, (Eds.), Black children: Social. Educational, and parental environments, (33-51). Newbury Park: Sage. Branch, C., \& Newcombe, N. (1980). Racial attitudes of Black preschoolers as related to parental Civil Rights activism. Merril-Palmer Quarterly, 26(4), 425-428. Branch, C. W., \& Newcombe, N. (1986). Racial attitude development among young Black children as a function of parental attitudes: A longitudinal and cross-sectional study. Child Development, 57, 712-721. Carter, R. T. (1991). Racial identity attitudes and 
psychological functioning. Journal of Multicultural Counseling and Development, 19, 105-114. Chang, E., \& Ritter, E. (1976). Ethnocentrism in Black college students. Journal of Social Psychology, 100, 89-98.

Clark K., \& Clark, M. (1939). The development of consciousness of self and the emergence of racial identity in Negro preschool children. Journal of Social Psychology, 10, 591-599.

Craig-Bray, C., \& Adams, G. R. (1986). Different methodologies in the assessment of identity: Congruence between self-report and interview techniques? Journal of Youth and Adolescence, 15(3), 191-204. Cross, W. E. (1971). Toward a psychology of Black liberation: The Negro-to-Black conversion experience. Black World, 20, 13-27.

Cross, W. E. (1985). Black identity: Rediscovering the distinction between personal identity and reference group orientation. In M. B. Spencer, G. K. Brookins, \& W. R. Allen (Eds.), Beginnings: The social and affective development of Black children. Hillsdale: Lawrence Erlbaum Associates.

Cross, W. E. (1987). A two-factor theory of Black identity: Implications for the study of identity development in minority children. In J. S. Phinney \& M. J. Rotheram, (Eds.), Children's ethnic socialization: Pluralism and 
development, (117-133). Newbury Park: Sage. Cross, W. E. (1991). Shades of Black: Diversity in African-American identity. Philadelphia: Temple University Press. Cummings, C., \& Carrere, R. (1975). Black culture, Negroes, and colored people: Racial image and self-esteem among Black adolescents. Phylon, 36(3), 238-248.

Demo, D. H., \& Hughes, M. (1990). Socialization and racial identity among Black Americans. Social Psychology ouarterly, 53(4), 364-374. Eddie-Quarterly, R. (1994). Who said Black is beautiful? Psych Discourse, 25(3), 8-10. Fordham, S. (1988). Racelessness as a factor in Black students' school success: Pragmatic strategy or Pyrrhic victory? Harvard Educational Review, 58(1), 54-84. Ford-Harris, D. Y., Schuerger, J. M., \& Harris, J. J. (1991). Meeting the psychological needs of gifted Black students: A cultural perspective. Journal of Counseling and Development, $69(6), 577-580$.

Ford, D. Y., Harris, J. J., \& Schuerger, J. M. (1993).

Racial identity development among gifted Black students: Counseling issues and concerns. Journal of Counseling and Development, 71, 409-417.

Gay, G. (1978). Ethnic identity in early adolescence: Some implications for instructional reform. Educational Leadershiv, 35, 649-655. 
Greene, B. A., (1992a). Racial socialization as a tool in psychotherapy with African American children. In L. A. Vargas, \& J. D. Koss-Chioino, (Eds.), Working with culture: Psychotherapeutic interventions with ethnic minority children and adolescents, (63-81). San Francisco: Jossey-Bass.

Greene, B. A. (1992b). African-American women: The burden of racism and sexism. AHA Newsletter, 20-23.

Gushue, G. V. (1993). Cultural-identity development and family assessment: An interaction model. The counseling Psychologist, 21, 487-513.

Harrison, A. O. (1985). The Black family's socializing environment: Self-esteem and ethnic attitude among Black children. In H. P. McAdoo, \& J. L. McAdoo (Eds.), Black children: Social, educational, and parental environments, (174-193). Newbury Park: Sage. Harrison, A. O., Wilson, M. N., Pine, C. J., Chon, S. Q., Buriel, R. (1990). Family ecologies of ethnic minority children. Child Development, 61, 347-362.

Helms, J. E. (1989). Considering some methodological issues in racial identity counseling research. The counseling Psychologist, 17(2), 227-252.

Helms, J. E. (1990). Black and white racial identity: Theory, research, and practice. New York: Greenwood Press.

Herbert, J. L. (1990). Integrating race and adult 
psychosocial development. Journal of Organizational Behavior, 11, 433-446.

Hopson, D. P., \& Hopson, D. S. (1990). Different and wonderful: Raising Black children in a race-conscious society. New York: Prentice Hall Press. Jackson, J. S., McCullough, W. R., Gurin, G. (1988).

Family, socialization environment, and identity development in Black Americans. In H. P. McAdoo, (Ed.), Black families (2nd ed.), (242-256). Newbury Park: Sage.

Johnson, R. (1980). Black Parental Attitude Scale manual. St. Louis: Black Studies Institute. Katz, P. A. (1987). Developmental and social processes in ethnic attitudes and self-identification. In J. S. Phinney \& M. J. Rotheram, (Eds.), Children's ethnic socialization: Pluralism and development, (92-102). Newbury Park: Sage. MCAdoo, J. L. (1985). Modification of racial attitudes and preferences in young Black children. In H. P. McAdoo, \& J. L. McAdoo (Eds.), Black children: Social and educational, and parental environments, (243-256). Newbury Park: Sage. Myers, L. J., Speight, S. L., Highlen, P. S., Cox, C. I., Reynolds, A. L., Adams, E. M., \& Hanley, C. P. (1991). Identity development and worldview: Toward an optimal conceptualization. Journal of counseling and 
Development, $\underline{70}, 54-70$

Nobles, W. W. (1989). Psychological Nigrescence: An Afrocentric review. The counseling Psychologist, 17, 253-257 .

Parham, T. A. (1989). Cycles of psychological nigrescence. The counseling Psychologist, 17(2), 187-226. Parham, T. A. (1993). Psychological storms: The AfricanAmerican struggle for identity. Chicago: AfricanAmerican Images.

Parham, T. A., \& Helms, J. E. (1981). The influence of Black students' racial identity attitudes on preferences for counselor's race. Journal of Counseling Psycholegy, $\underline{28}(3), 250-257$.

Parham, T. A., \& Helms, J. E. (1985a). Attitudes of racial identity and self-esteem of Black students: An exploratory investigation. Journal of College student Personnel, 26(2), 134-147.

Parham, T. A., \& Helms, J. E. (1985b). Relation of racial identity attitudes to self-actualization and affective states of Black students. Journal of counseling Psychology, 32(3), 431-440.

Parham, T. A., \& Williams, P. T. (1993). The relationship of demographic and background factors to racial identity attitudes. Journal of Black Psychology, 19(1), 7-24. Peters, M. F. (1985). Racial socialization of young Black children. In H. P. MCAdoo, \& J. L. MCAdOo (Eds.), Black 
children: Social, educational, and parental

environments, (159-173). Newbury Park: Sage.

Phinney, J. S. (1989). Stages of ethnic identity

development in minority group adolescents. Journal of Early Adolescence, $9(1-2), 34-49$.

Phinney, J. S. (1991). Ethnic identity and self-esteem: A review and integration. Hispanic Journal of Behavioral Sciences, 13(2), 193-208.

Phinney, J. S. \& Rotheram, J. (1987). Children's ethnic socialization: Pluralism and development. Newbury Park: Sage.

Phinney, J. S., \& Tarver, S. (1988). Ethnic identity search and commitment in Black and white eighth graders. Journal of Early Adolescence, 8 (3), 265-277. Ponterotto, J. G., \& Wise, S. L. (1987). Construct validity study of the Racial Identity Attitude Scale. Journal of Counseling Psychelogy, 34, 218-223. Pouissant, A. F. (1990). Forward. In D. P. Hopson, \& D. S. Hopson, Different and wonderful: Raising Black children in a race-conscious society. New York: Prentice Hall Press.

Ramsey, P. G. (1987). Young children's thinking about ethnic differences. In J. S. Phinney \& M. J. Rotheram, (Eds.), Children's ethnic socialization: Pluralism and development, (56-72). Newbury Park: Sage. Reynolds, A. L., \& Pope, R. L. (1991). The complexities of 
diversity: Exploring multiple oppressions. Journal of Counseling and Development, 70, 174-180.

Roberts, A., Mosiey, K. Y., \& Chamberlain, M. W. (1975). Age differences in racial self-identity of young Black girls. Psychological Reports, 37, 1263-1266.

Rotheram, M. J., \& Phinney, J. S. (1987). Introduction:

Definitions and perspectives in the study of children's ethnic socialization. In J. S. Phinney \& M. J. Rotheram, (Eds.), children's ethnic socialization: Pluralism and development, (10-28). Newbury Park: Sage. Sanders Thompson, V. L. (1994). Socialization to race and its relationship to racial identification among African-Americans. Journal of Black Psychology, 20, $175-188$.

Schofield, J. W. \& Anderson, 1987). Combining quantitative and qualitative components of research on ethnic identity and intergroup relations. In J. S. Phinney \& M. J. Rotheram, (Eds.), Children's ethnic socialization: Pluralism and development, (252-273). Newbury Park: Sage.

Smith, E. J. (1989). Black racial identity development:

Issues and concerns. The counseling Psychologist, 17, 277-288.

Smith, E. J. (1991). Ethnic identity development: Toward the development if a theory within the context of majority/minority status. Journal of counseling and 
Development, 70, 181-188.

Spencer, M. B. (1982a). Preschool children's social

cognition and cultural cognition: A cognitive

developmental interpretation of race dissonance

findings. The Journal of Psychology, 112, 275-286.

Spencer, M. B. (1982b). Personal and group identity of

Black children: An alternative synthesis. Genetic

Psychology Monographs, 106, 59-84.

Spencer, M. B. (1983). Children's cultural values and

parental child rearing strategies. Developmental

Review, 3, 351-170.

Spencer, M. B. (1987). Black children's ethnic identity

formation: Risk and resilience of castelike minorities.

In J. S. Phinney \& M. J. Rotheram, (Eds.), Children's

ethnic socialization: Pluralism and development,

(10-28). Newbury Park: Sage.

Spencer, M. B. (1988). Self-concept development. In D. T.

Slaughter (Ed.), Perspectives on Black child

development: New directions for child development (59-

72). San Francisco: Jossey-Bass.

Spencer, M. B. (1990). Parental values transmission:

Implications for the development of African-American

children. In H. E. Cheatham \& J. B. Stewart, (Eds.),

Black families: Interdisciplinary perspectives. New

Brunswick: Transaction.

Spencer, M. B., Dobbs, B., \& Swanson, D. P. (1988). African 
American adolescents: Adaptational processes and socioeconomic diversity in behavioral outcomes. Journal of Adolescence, 11, 117-137.

Spencer, M. B., Swanson, D. P., \& Cunningham, M. (1991). ethnicity, ethnic identity, and competence formation: Adolescent transition and cultural transformation. Journal of Negro Education, $\underline{60}(3), 366-387$. Stevenson, H. C. (1993). Validation of the Scale of Racial Socialization for African American Adolescents: A preliminary analysis. Psych Discourse, 24(12), 7-10. Thornton, M. C., Chatters, L. M., Taylor, R. J., \& Allen, W. R. (1990). Sociodemographic and environmental correlates of racial socialization by Black parents. Child Development, 61, 401-409. Ward, J. V. (1990). Racial identity formation and transformation. In C. Gilligan, N. D. Lyons, \& T. J. Hanmer, (Eds.), Making connections: The relational worlds of adolescent girls at Emma Willard School. Cambridge: Harvard University Press. Whaley, A. L. (1993). Self-esteem, cultural identity, and psychosocial adjustment in African-American children. Journal of Black Psychology, 19, 406-422. 
VITA

The author, Anita Jones Thomas, M.A., is the daughter of Melvin and Bernice Jones. She was born on July 26, 1967. Her elementary education was obtained in the public schools of Louisville, Kentucky, and her secondary education in the same city at duPont Manual Magnet High School, where she graduated in May, 1985.

In September, 1985, Mrs. Thomas entered Northwestern University, Evanston, Illinois, and received the degree of Bachelor of Science in Education in June, 1989. She entered Loyola University Chicago in August, 1989, where she received a Masters of Arts in Community Counseling in May, 1992. Mrs. Thomas completed her predoctoral internship at the Allendale Association from August, 1993 to August, 1994. 


\section{DISSERTATION APPROVAL SHEET}

The dissertation submitted by Anita Jones Thomas, M.A. has been read and approved by the following committee:

Suzette L. Speight, Ph.D., Director

Assistant Professor, Counseling Psychology

Loyola University Chicago

V. Scott Solberg, Ph.D.

Assistant Professor, Counseling Psychology

Loyola University Chicago

Gloria Lewis, Ph.D.

Professor, Counseling Psychology

Loyola University Chicago

The final copies have been examined by the director of the dissertation and the signature which appears below verifies the fact that any necessary changes have been incorporated and that the dissertation is now given final approval by the committee with reference to content and form.

The dissertation is, therefore, accepted in partial

fulfillment of the requirements for the degree of Doctor of Philosophy.
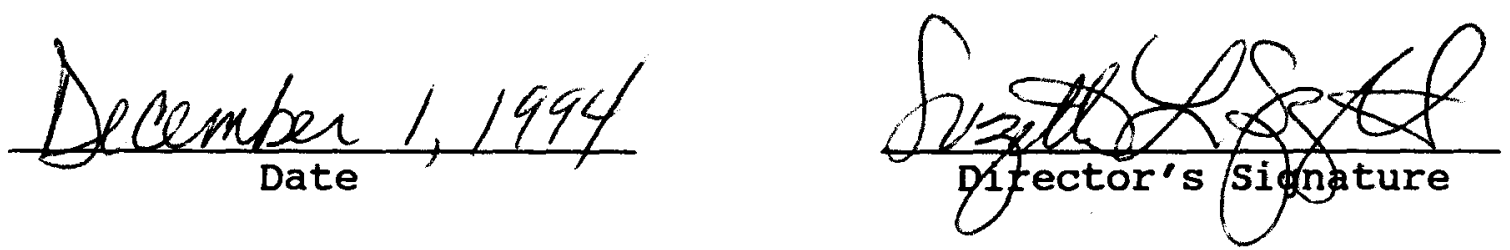